\title{
1. THE GEOLOGICAL EVOLUTION OF THE TYRRHENIAN SEA: AN INTRODUCTION TO THE SCIENTIFIC RESULTS OF ODP LEG 107
}

\author{
Kim Kastens ${ }^{2}$ and Jean Mascle ${ }^{3}$
}

\begin{abstract}
The goal of this chapter is to integrate old and new data from the Tyrrhenian Sea into an internally consistent, chronologically ordered, interdisciplinary story that can serve as an overview of the highlights of Leg 107 , or as an introduction to more detailed studies in this volume.

Among the more intriguing aspects of this Tyrrhenian research are the following:

1. The extensional basin developed within thickened continental crust on the site of former orogenic belts. Extension in the Tyrrhenian proceeded simultaneously with compression in the circum-Tyrrhenian.

2. The onset of major rifting in the Tyrrhenian ( $\sim 9 \mathrm{Ma})$ coincided with a major CCW change in the direction of Africa/Europe motion such that the direction of major plate motion was more nearly parallel to the dip of the downgoing slab under Calabria. This coincidence suggests that the decrease in obliquity of convergence may have triggered or favored backarc extension.

3. Rifting was rapid and diachronous across the Sardinia margin: on the upper margin, subsidence and tilting of fault blocks were most active in the Tortonian to Messinian, whereas on the lower margin these symptoms of rifting are concentrated in the Messinian to Pliocene sequences. Such diachronous development is compatible with an evolution controlled by east-dipping, low-angle detachment faults, accompanying "rollback" of the hinge zone of the downgoing African plate.

4. Of the two small basalt-floored sub-basins, the one closer to the subduction zone (Marsili Basin) is younger. This observation is compatible with development controlled by "rollback" of the downgoing slab.

5. Rapid subsidence has been documented in the younger of the two basalt-floored basins. Rapid subsidence is predicted for a spreading segment that is short in the along-strike direction because of along-strike heat loss.

6. A body of mantle-derived peridotite subcrops in the axis of the Vavilov Basin. Its origin at such a shallow crustal depth remains mysterious, but unroofing by shallow-dipping, deep-cutting detachment faults may have been important.

7. The Messinian salinity crisis produced a wide variety of lithologies, including subaerial conglomerates, dolomitic mudstones, clastic lacustrine sediments, and laminated gypsum. Magnetostratigraphy of the unusually complete lower Pliocene section at Site 652 places the Miocene/Pliocene boundary at $4.8 \mathrm{Ma}$, during a eustatic rise in sea level that may have increased the rate of inflow of Atlantic-derived water into the Mediterranean and thus ended the evaporative phase. Establishment of stable oceanographic conditions occurred within approximately $240,000 \mathrm{yr}$ after the initial marine incursion.

8. In the modern Mediterranean, evaporation exceeds runoff plus rainfall, and the circulation pattern is anti-estuarine, i.e., Atlantic-derived water flows in (eastward) at the surface and deep/intermediate water flows out near the seafloor. Early Pliocene circulation, on the contrary, was estuarine. Leg 107 stable isotope data suggest that the change to the modern hydrographic regime occurred about $2.5 \mathrm{Ma}$, in response to increased aridity associated with the beginning of Northern Hemisphere glaciation.

9. Tephra layers are present in the Messinian sediments and abundant in Pleistocene sediment, but totally lacking in Pliocene sediments. Thus, either the Pliocene-age Vavilov Basin opened in a backarc setting without accompanying explosive arc-type vulcanism, or the volcanic arc was underwater.
\end{abstract}

\section{INTRODUCTION}

The goal of this chapter is to tie a common thread around the diverse studies resulting from Ocean Drilling Program Leg 107 in the Tyrrhenian Sea. To provide a context for new readers, we begin with a brief synopsis of the objectives of the leg and the significance of each site. The body of the chapter then outlines the geological evolution of the Tyrrhenian Sea with emphasis on the late Miocene to Pleistocene time interval covered by Leg 107 samples. By this chronological approach, we hope to emphasize the interrelationships among tectonic, volcanic, oceanographic, climatic, and diagenetic processes active throughout the history of the Tyrrhenian.

\footnotetext{
${ }^{1}$ Kastens, K. A., Mascle, J., et al., 1990. Proc. ODP, Sci. Results, 107: College Station, TX (Ocean Drilling Program).

2 Lamont-Doherty Geological Obseratory of Columbia University, Palisades, NY 10964.

${ }^{3}$ Laboratoire de Geodynamique Sous-Marine, B.P.48, 06230 Villefranche sur Mer, France.
}

This chapter can be approached on two levels: for the casual reader, the bold outline of the story is presented in the main text. For the more serious reader, extensive documentation, speculation, alternate hypotheses, caveats, numbers, and details are available in the Appendix, cross-referenced to the text by numbers in square brackets.

Readers interested primarily in tectonic insights from Leg 107 will find additional discussion in Kastens, et al. (1988), Mascle et al. (1988) and Sartori (this volume). For additional background on circum-Tyrrhenian geology, see Sartori et al. (1987); for a review of regional geophysics, see Rehault et al. (1987b); for additional information on individual sites, see Shipboard Scientific Party (1987a through 1987g). The International Bathymetric Chart of the Mediterranean (sheets 2, 3, and 8), the Tectonic Map of Italy (Funiciello et al., 1981), and the palinspastic maps of Dercourt et al. (1986), Hill and Hayward (1988), or Dewey et al. (in press) will help provide a geographic context for our discussion. 
The stratigraphic framework assumed in this chapter is based on biostratigraphic work of Rio, Raffi, and Villa (this volume); Glacon, Rio, and Sprovieri (this volume); Mueller (this volume); and Sprovieri and Hasegawa (this volume); isotope stratigraphies of Vergnaud Grazzini et al. (this volume) and McKenzie, Palmer, and Mueller (this volume); and magnetostratigraphy of Channell, Torii, and Hawthorne (this volume). Correlations among various Leg 107 chronologies have been assembled by Channell, Rio, et al. (this volume), and correlations with land stratotypes are presented by Rio, Sprovieri, and Channell (this volume).

\section{GENERAL OBJECTIVES}

The Tyrrhenian Sea is a region of extensional tectonism within the overriding plate of a convergent plate margin. As such, the Tyrrhenian qualifies as a species of "backarc" basin. Rather than one well-defined oceanic spreading axis, the Tyrrhenian has two basalt-floored sub-basins: the Marsili Basin and the Vavilov Basin (Fig. 1). By drilling to basement in each basin, we hoped to find clues to the timing of basaltic crust formation and perhaps the nature of the plumbing system leading to this double-basin geometry. An attractive hypothesis we wished to test was the idea that the Tyrrhenian had formed by "rollback" or "passive-subduction" of the downgoing slab of African lithosphere (Ritsema, 1979; Malinverno and Ryan, 1986); such a mechanism requires that the western (Vavilov) sub-basin be older than the eastern (Marsili) sub-basin.

Unlike the majority of backarc basins that have formed in intra-oceanic settings, the Tyrrhenian Sea split a preexisting continent. As a result, the margins of the Tyrrhenian are passive continental margins; in particular, the eastern Sardinia margin comprises a series of fault-bounded, tilted blocks similar to those seen on classic rifted passive margins bounding major ocean basins. Another objective of Leg 107 was to explore the timing and rate of extension and subsidence on the passive margin of Sardinia. We were eager to compare the rates and sequence of events in this young backarc setting with those observed at classic open-ocean passive margins, and to compare the timing of extension in the basin with the timing of compression in the circum-Tyrrhenian orogenic belts.

A third objective of Leg 107 was to obtain a complete Pliocene-Pleistocene pelagic stratigraphic section. The stratotype sections for Neogene stages are located in Italy; however, there has been no consensus on whether biostratigraphic events occurred at exactly the same time in the semi-enclosed basin of the Mediterranean as they did in the open oceans. Thus, the stratigraphic community desired a "deep-sea reference section" on which to intercalibrate time scales based on stable isotopes, paleomagnetics, biostratigraphy, and tephrochronology. The Pliocene-Pleistocene history of the Mediterranean also poses intriguing questions in paleoceanography and paleoclimate. What was the sequence of events by which the Tyrrhenian was refilled and oceanic circulation restored following the Messinian salinity crisis? When did the present anti-estuarine circulation pattern (Atlantic-derived water flowing eastward near the sea surface; dense salty water flowing westward near the seafloor) become established? How did the Mediterranean respond to the glacial/interglacial climatic and sea-level fluctuations of the late Pliocene and Pleistocene?

\section{SITE BY SITE OBJECTIVES}

Site 650 (Shipboard Scientific Party, 1987a; Fig. 2) was drilled near the western rim of the southeastern of the two deep Tyrrhenian Basins, the Marsili Basin. Primary objectives included determining the nature of the Marsili Basin basement (basalt? volcaniclastics? an unusual Messinian facies?), and determining the timing of basin formation. Based on a dense seis- mic grid, the site was positioned to sample one of the oldest sediment pockets in the basin, and thus set an older limit on the age of the basin.

Site 651 (Shipboard Scientific Party, 1987b; Fig. 3) was drilled near the axis of the Vavilov basin. Again the objective was to constrain the age of the basin. However, since the structurally deepest part of the basin was filled with more than $1 \mathrm{~km}$ of potentially unstable turbidites, the site was located on the flank of a basement swell.

Site 652 (Shipboard Scientific Party, 1987c; Fig. 4) was drilled in a tilted fault-bounded block on the lower continental margin of Sardinia. Seismic-reflection profiles across the site revealed a geometry suggestive of prerift, synrift, and post-rift sediments: subparallel, landward-dipping, deep-lying reflectors interpreted as sediments deposited before tilting began; a landward-dipping wedge interpreted as sediments deposited while the block was tilting; and untilted reflectors conformable with the seafloor interpreted as sediments deposited after most motion on the bounding faults of this block had stopped. The primary goal of the site was to date the prerift/synrift and the synrift/post-rift contacts deduced from the seismic stratigraphy.

Site 653 (Shipboard Scientific Party, 1987d; Fig. 5) was planned as a "deep-sea stratigraphic type-section" for Mediterranean Neogene pelagic sediments. The site was a reoccupation of DSDP Site 132, which had recovered the most nearly complete Neogene section in the Mediterranean. Two adjacent holes were cored with the advanced piston coring system to obtain the high recovery and undisturbed samples required for a detailed intercalibration of biostratigraphic, magnetostratigraphic, tephrochronologic, and isotopic time scales.

Site 654 (Shipboard Scientific Party, 1987e; Fig. 6) was drilled on the upper Sardinia margin on a tilted fault block tectonically analogous to the setting of Site 652. Again, the goal was to date the prerift/synrift and synrift/post-rift contacts. By drilling two sites on similar fault-bounded tilted blocks, we could compare the rates and timing of rifting on the upper and lower margin.

Site 655 (Shipboard Scientific Party, 1987f; Fig. 7) was drilled on a north-northeast/south-southwest trending basement ridge near the western edge of the Vavilov Basin. The primary goal of this site was to determine the nature of the basement, which had been hypothesized as a protrusion of mantle peridotite emplaced at the end of the rifting phase of basin evolution.

Site 656 (Shipboard Scientific Party, 1987g; Fig. 8) was drilled on the lower Sardinia continental margin in a half-graben adjacent to that where Site 652 had been located. The seismic reflection profile indicated a thin cover of synrift and postrift sediments, offering one last chance to date the prerift/synrift contact.

\section{CHRONOLOGY}

\section{Pre-Miocene}

A few tantalizing clues about the prerifting events that shaped the Tyrrhenian continental basement can be extracted by examination of the rock types and mineral associations in detrital sands and gravels. Such lines of reasoning draw heavily on analogy with circum-Tyrrhenian land geology.

\section{Paleozoic}

During the late Paleozoic, a complex paleogeography of small oceanic fragments and/or continental rifts, covering most of what is now Europe, was gradually consolidated in a series of collisions (Bard et al., 1980; Zwart and Dornsiepen, 1980). The resulting folding, faulting, metamorphism, and magmatism comprise the Hercynian (or "Variscan") orogeny. The broad belt of 


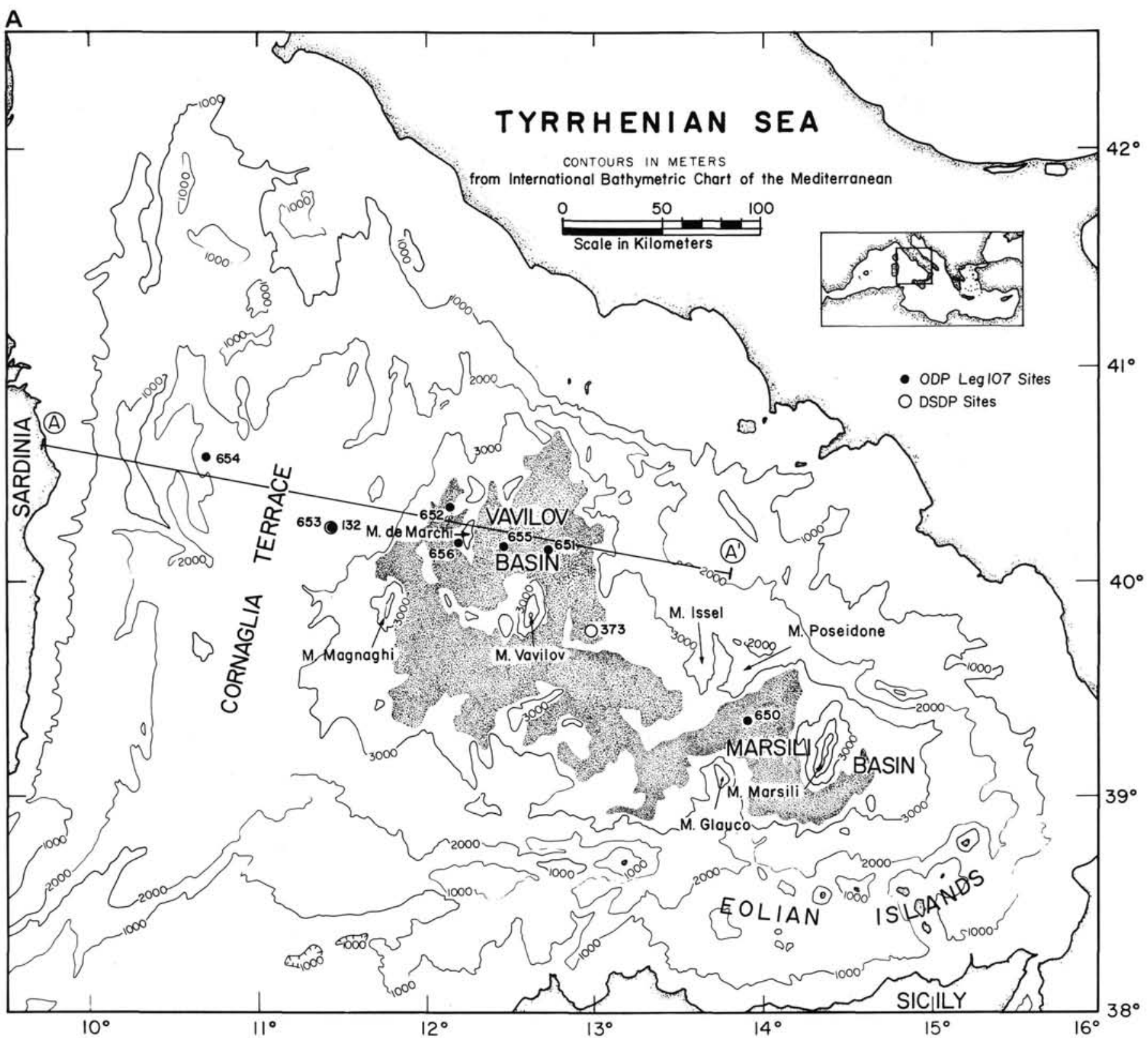

(A)

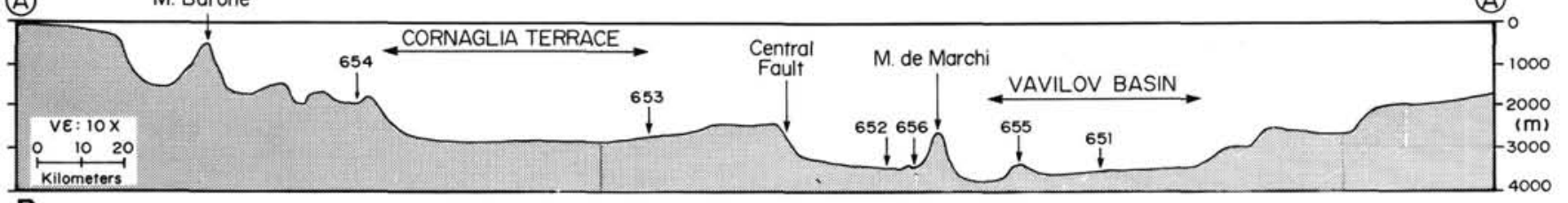

B

Figure 1. A. Location map. The Tyrrhenian Sea is the small triangular sea surrounded by mainland Italy, Sicily, Sardinia, and Corsica. During Leg 107 , a WNW/ESE transect of seven sites was drilled across the basin. The shaded area is deeper than $3400 \mathrm{~m}$ and is approximately coincident with the bathyal plain. B. Bathymetric profile along line of drill sites.

Hercynian metamorphic and plutonic rocks includes parts of Sardinia and Corsica (Bourrouilh et al., 1980; Sartori et al., 1987 and references therein). Sartori et al. (this volume; also Shipboard Scientific Party, 1987e, p. 766) recognize distinctive green schist facies, metasedimentary pebbles in the basal conglomerate (lithologic Unit VI) of Site 654, which they correlate with Hercynian outcrops of Sardinia. The protoliths of the Site 654 samples would have been platform carbonates and possibly Devonian basinal carbonates. At Site 653, detrital sand grains include staurolite and chloritoid (Sartori et al., this volume, Table 1), implying provenance from a metamorphosed terrain (Borsetti et al., this volume). These observations at both Sites 
A

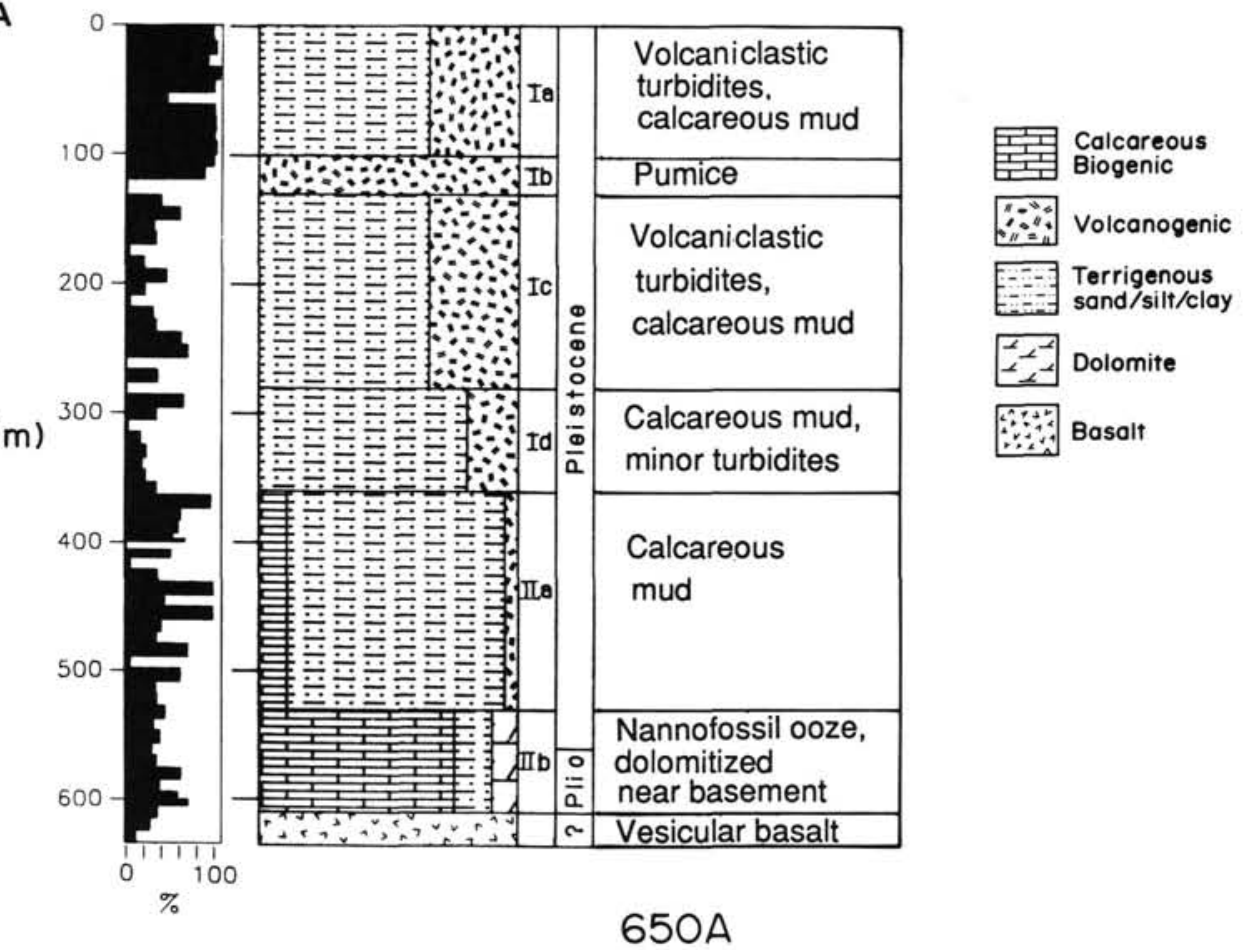

B

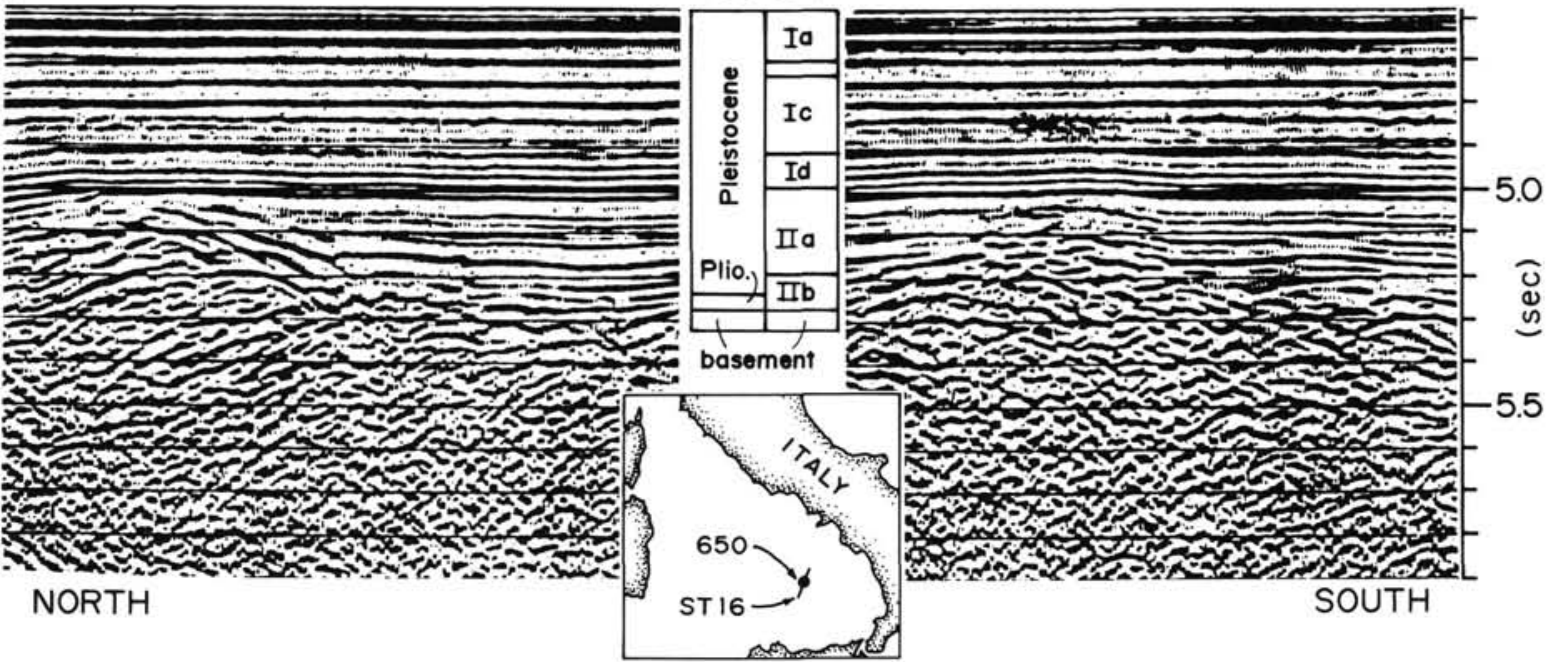

Figure 2. A. Core log indicating the lithologic units recovered at Site 650. The sediment classifications are as defined by Ocean Drilling Program (1984). The width of each vertical division within a given lithologic unit is proportional to the percentage of that lithology recovered in the unit. Bar graph at left indicates percent of recovery in each core. The percentage of volcanogenic sediments increases upsection throughout the sediment column. A thick pumice layer (Unit IIb) correlates with a seismic reflector that can be traced throughout the Marsili Basin. B. Seismic reflection profile showing the location of Site 650 in the turbidite-filled Marsili Basin. Simplified core log inserted into a break in the profile (no data missing) indicates ages (left) and lithologic unit numbers (right); correlation between cored depths and seismic profile is based on acoustic velocities measured in cored samples and calculated from multichannel seismic data.

653 and 654 are compatible with the suggestion (Sartori et al., this volume) that the area which is now the upper Sardinia margin was part of the Hercynian orogenic belt.

\section{Mesozoic}

At the dawn of the Mesozoic, the region that was to become the continental basement of the western Tyrrhenian Sea constituted a bit of the Pangea supercontinent, located west of the Paleotethyan Ocean (Dewey et al., 1973, their Fig. 8B; Robertson and Dixon, 1984, their Fig. 2; Sengor et al., 1984, their Fig.
7A). Unmetamorphosed bioclastic limestones bearing crinoid fragments, brachiopods, and abundant foraminifers of early Triassic age were found in the basal conglomerate of Site 654 (lithologic Unit VI; Sartori et al., this volume). These observations suggest that the present-day Sardinia margin shared the shelf-carbonate environment that characterized Sardinia, Corsica, and, indeed, a broad belt around the whole perimeter of the paleo-Tethys (Dewey et al., 1973).

During the middle to late Triassic, rifting began to split Europe (including Iberia), from Africa (including a northward prom- 
A
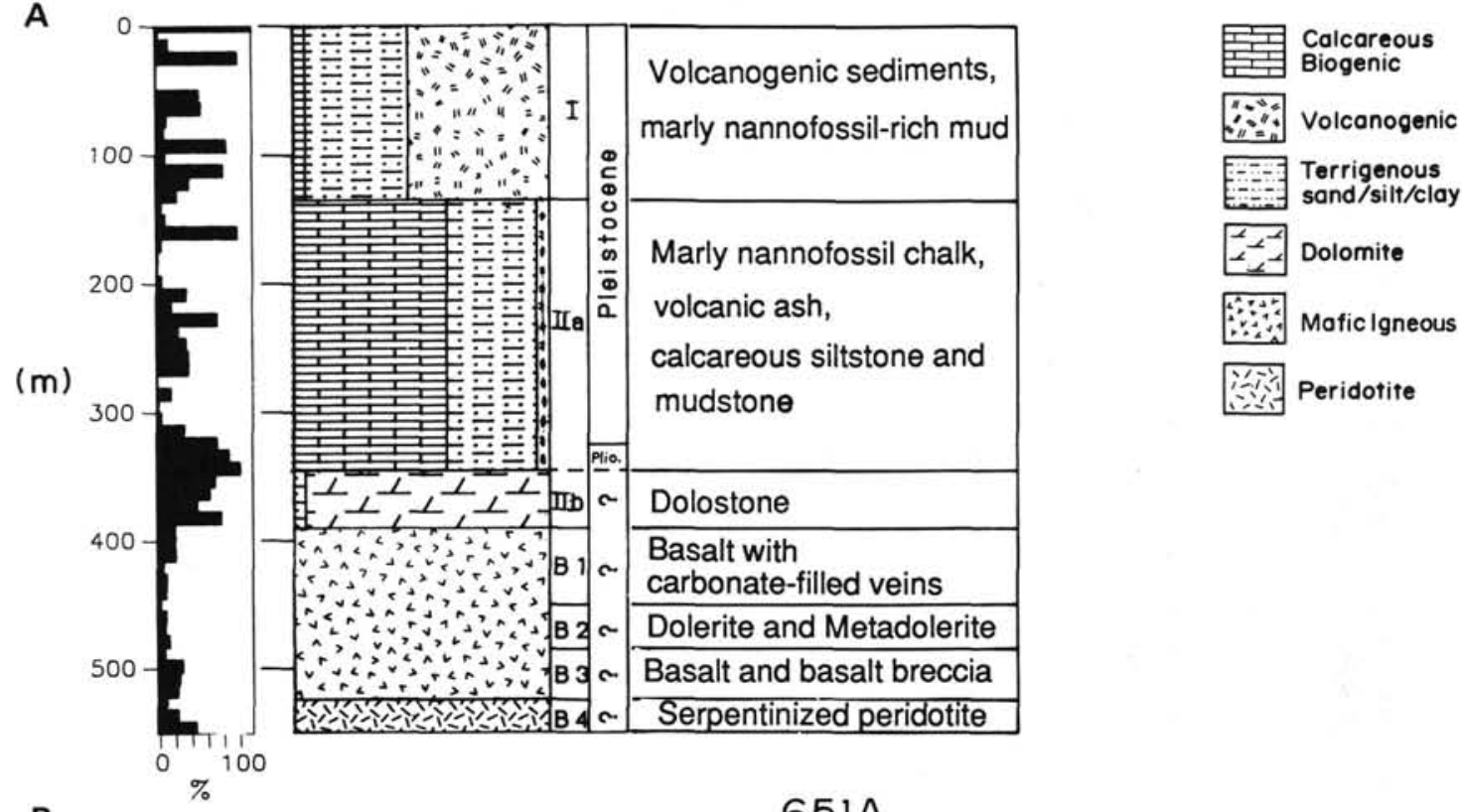

B

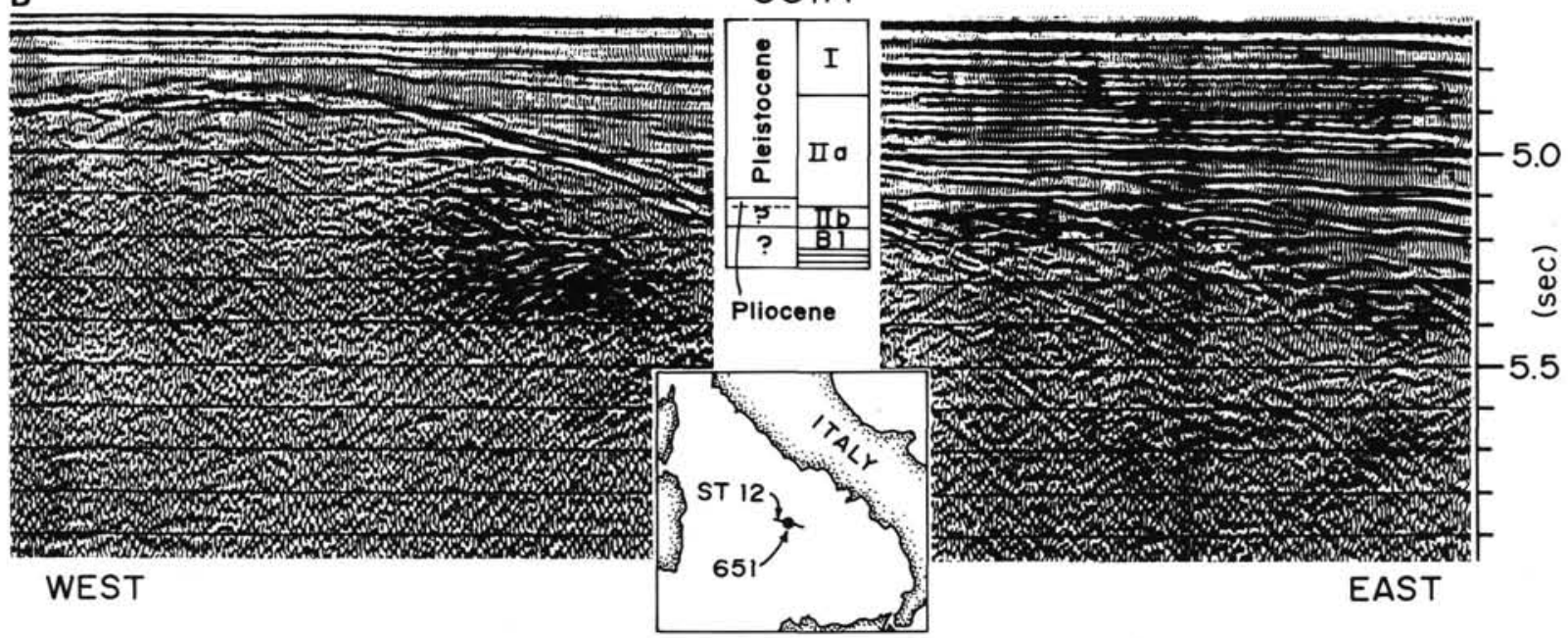

Figure 3. A. Core log indicating the lithologic units identified at Site 651. Note the complex nature of the basement, with a unit of dolerites, metasediments, metadolerite, and altered peridotite fragments sandwiched between two layers of basalt and basalt breccia, all underlain by serpentinized peridotite. B. Seismic reflection profile showing the location of Site 651 on the flank of a basement swell in the Vavilov Basin.

ontory called "Adria" or "Apulia"; Channell et al., 1979). The split occurred south and east of Corsica-Sardinia (Abbate et al., 1980, their Fig. 5A; Channell et al., 1979, their Fig. 12), that is, in approximately the same lithosphere where the Tyrrhenian rifting would occur $200 \mathrm{~m} . \mathrm{y}$. later. The circum-Tyrrhenian, rifting-phase facies include dolomites, evaporites, limestones, and shales interbedded with volcanics (Channell et al., 1979; Ricou et al., 1986). No trace of Triassic rift facies has been identified in Leg 107 samples.

Rifting gave way to seafloor spreading in the Jurassic and Early Cretaceous (Boillot et al., 1984, their Fig. 1; Sengor et al., 1984, their Figs. 7C and 7D; Dercourt et al., 1986, their Pls. 13) to form the "Piemont-Ligurian ocean" or "Ligurian Tethys." This ocean probably never exceeded a few hundred kilometers in width (Treves, 1984) and may have been characterized by oblique, Gulf-of-California-style spreading in which long transform segments offset short spreading segments [1]. Metagabbro, metadolerite, and greenstone clasts of Site 656 (lithologic
Unit IV) are interpreted as remnants from this Mesozoic ocean (Sartori et al., this volume). Late Jurassic to mid-Cretaceous radiolarian-bearing biomicrites, found in the pebble layer of Site 652 (lithologic Unit IVC), were probably deposited in an open marine setting within this seaway. By analogy with subaerially exposed portions of the Ligurian ophiolite, Sartori et al. (this volume) argue that chert and metalimestone pebbles from Site 656 (lithologic Unit IV) may also have originated in this ocean.

The Ligurian Tethys seaway began to subduct during the mid-Cretaceous (Boillot et al., 1984; Dercourt et al., 1986, their Pl. 4; Harris, 1985; Van Wamel, 1987) [2]. By the end of the Cretaceous, subduction had rafted Calabria (the toe of modern Italy) into juxtaposition with eastern Sardinia (Dercourt et al., 1986, their Pl. 5), and slivers of oceanic crust and sediments had been abducted northwestward onto Corsica (Harris, 1985; Sartori et al., 1987 and references therein). Within the complex Late Cretaceous paleogeography of the Calabria/Sardinia collision zone, Rudistid carbonate platform fragments were reworked 

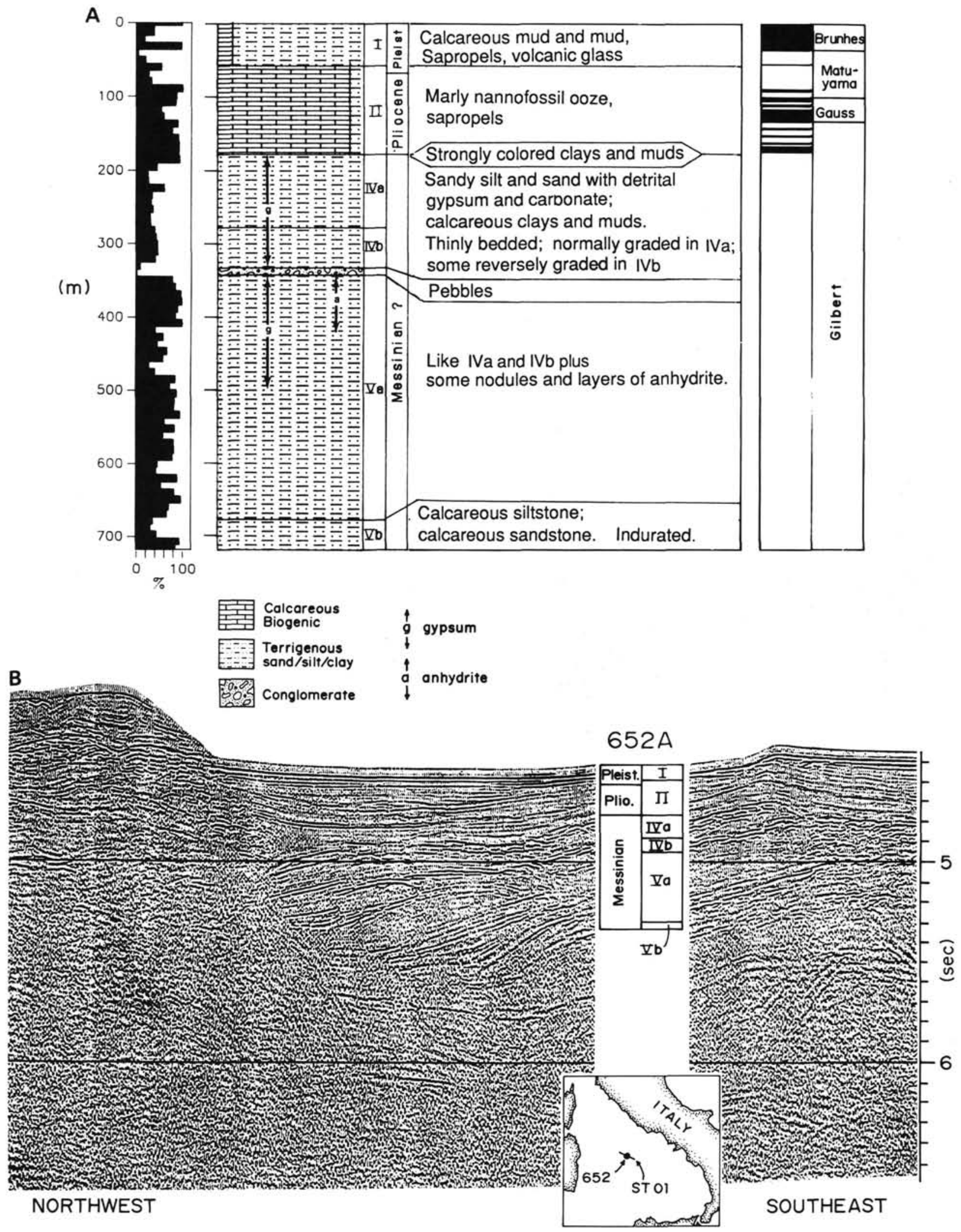

Figure 4. A. Core log indicating lithologic units recovered at Site 652 on the lower Sardinia margin. Lithologic Unit III, a 40-cm-thick transitional interval of bright red/brown/gray clays and muds, is too thin to indicate at this scale. Magnetostratigraphy is indicated to the right; the entire barren interval (lithologic Units IV and V) is thought to be in the lowermost reversed polarity event of the Gilbert epoch and thus Messinian in age. B. Seismic reflection profile across Site 652 on the lower Sardinia margin shows a fault-bounded, tilted block not unlike the tectonic setting of Site 654 . Our preferred interpretation of the seismic stratigraphy places the prerift/synrift and the synrift/postrift contacts, respectively, at 720 to $750 \mathrm{~ms}$ and 200 to $230 \mathrm{~ms}$ below the seafloor at the drill site. 
A
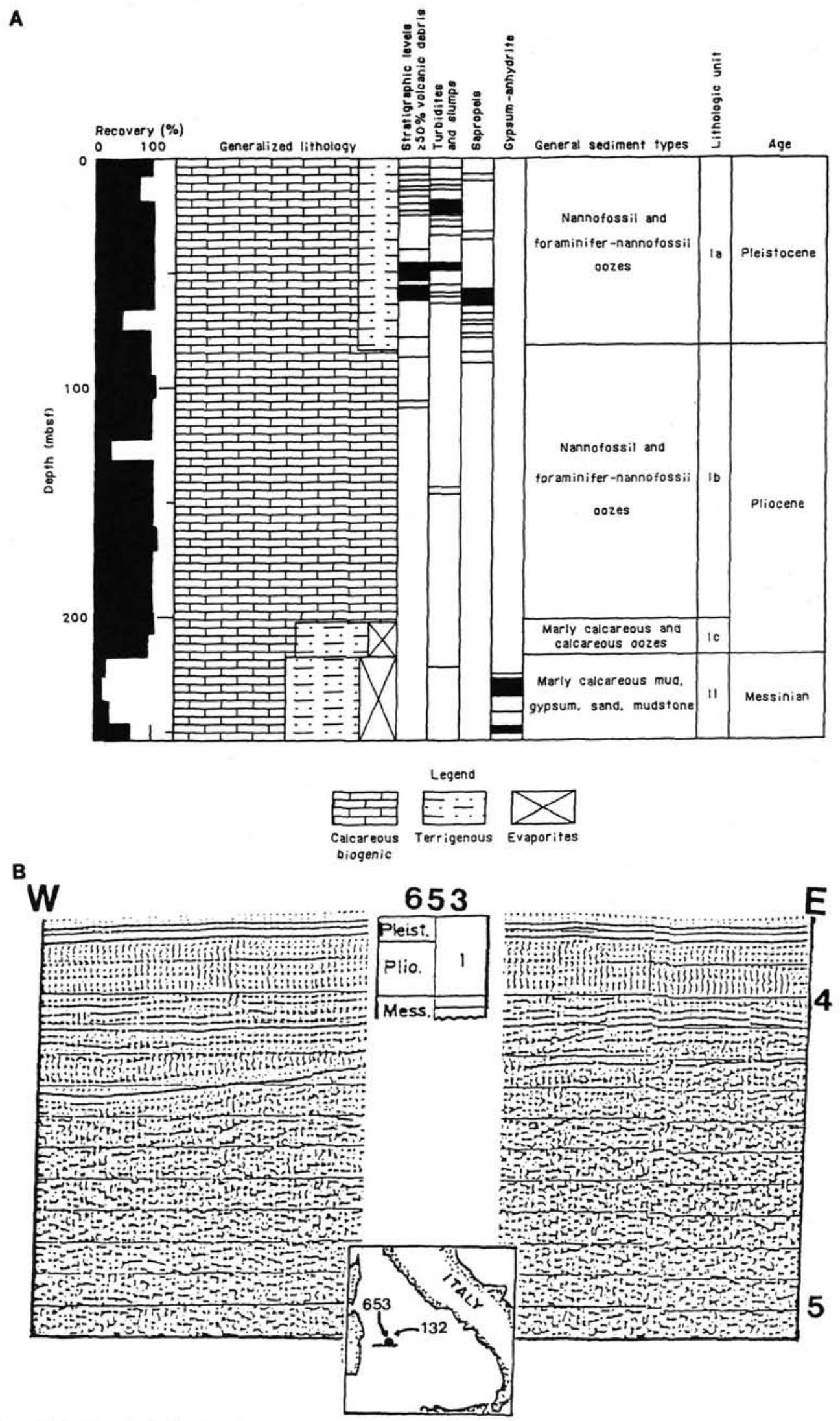

Figure 5. A. Core log indicating lithologic units identified at Site 653. The $\sim 210$-m-thick Pliocene-Pleistocene section is the focus of coordinated, high-resolution stratigraphic research. B. Seismic reflection profile showing the position of Site 653 on the eastern rim of the Cornaglia Basin. The presence of thick, halitebearing evaporites in the center of Cornaglia Basin (west of Site 653) is inferred from the seismic character. 


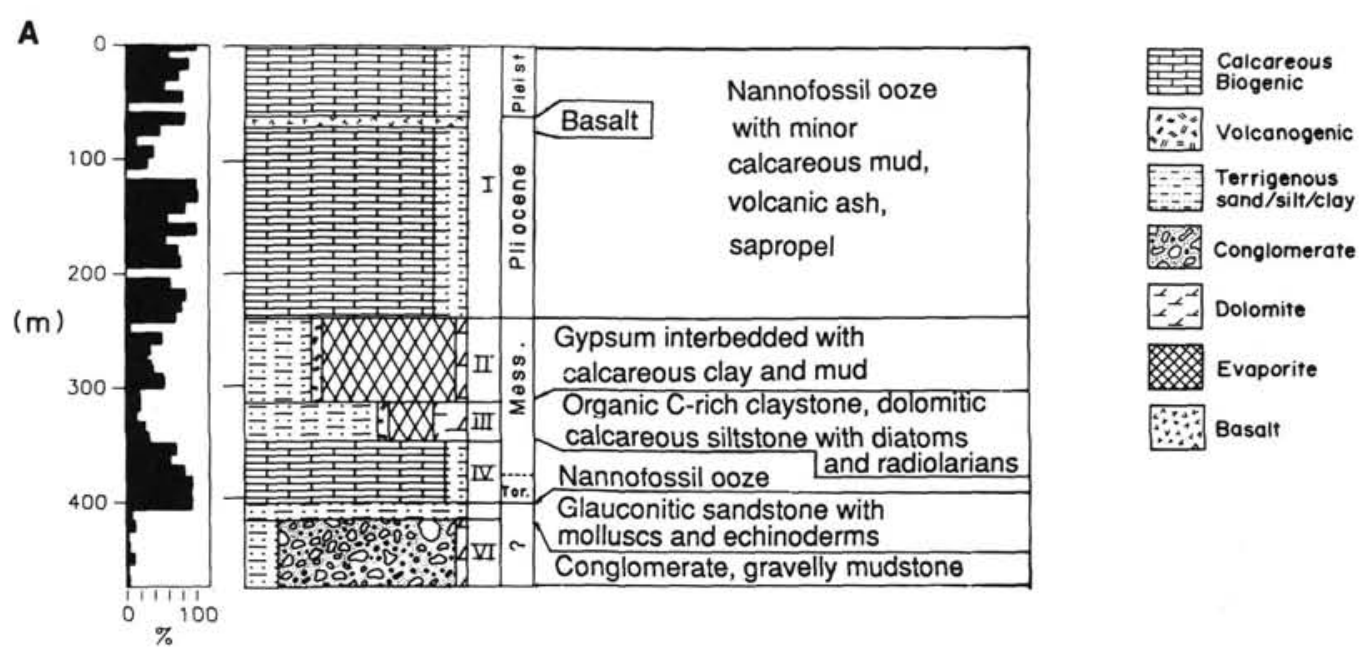

B

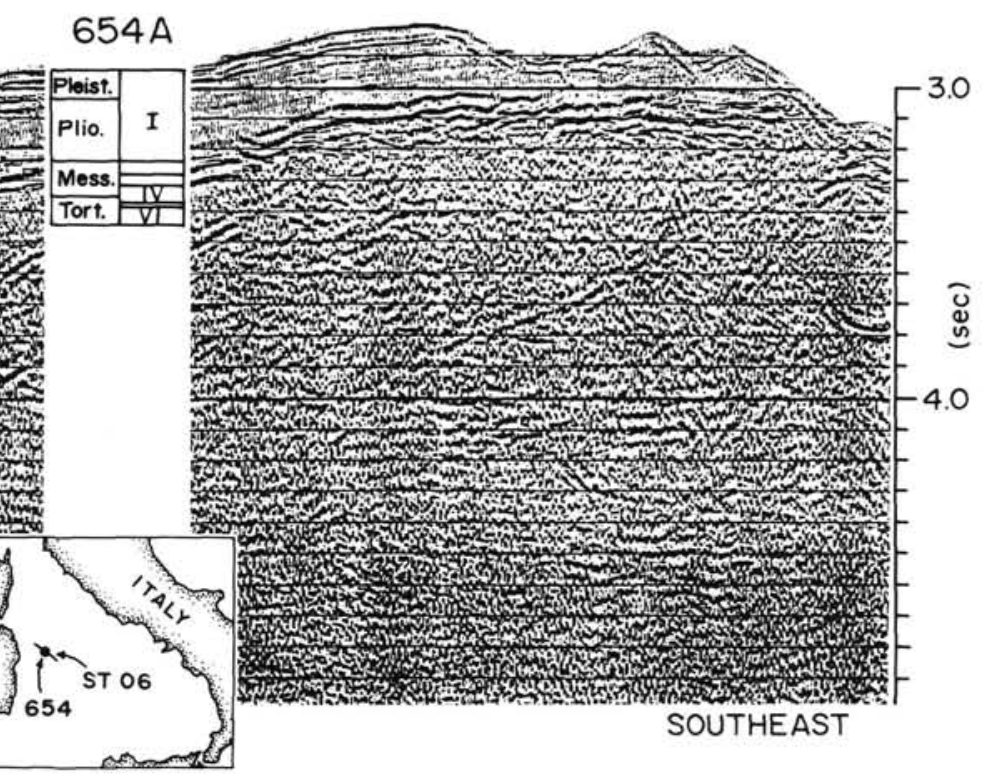

Figure 6. A. Core log indicating lithologic units identified at Site 654. Units VI, V, and IV record a transgressive sequence linked to tectonic subsidence. Units II and III record pre-evaporitic and evaporite-bearing phases of the Messinian salinity crisis. B. MCS reflection profile across Site 654. The geometry of the seismic units suggests prerift, synrift, and postrift deposits. Our preferred interpretation of the seismic stratigraphy places the prerift/synrift contact at $580 \mathrm{~ms}$ and the synrift/postrift transition at 300-320 $\mathrm{ms}$ below seafloor at the drill site.

into a deeper water facies to form a packstone recovered in Hole 652A (lithologic Unit IVC; Sartori et al., this volume; also Shipboard Scientific Party, 1987c, p. 416-417, pebble 5).

\section{Paleogene}

The suturing of Calabria to Sardinia left the region of the future Tyrrhenian Sea as a primarily shallow, carbonate-bearing sea, probably with locally emergent areas (Dercourt et al., 1986, their Pls. 6 and 7). As remnant of this time, drilling at Site 652 recovered a pebble containing large benthic foraminifers, bryozoans, red algae, echinid plates, and mollusk fragments indicative of a shallow-marine (less than 100-150 m) high-energy bank (Sartori et al., this volume; also Shipboard Scientific Party, 1987c, p. 417-418, pebble 1) [3].

In the Eocene, a north- to south-trending embayment of Mesozoic [4] oceanic crust persisted east and northeast of Calabria (Alvarez et al., 1974; Dercourt et al., 1986, their Pl. 7; Dewey et al., in press, their Fig. 5A). A westward- to northwestward-dip- ping subduction zone gradually consumed this oceanic remnant. Closure was diachronous, beginning in the north at the narrow end of the embayment and migrating southward toward the open end of the embayment. At the latitude of Corsica and northern Italy, consumption of oceanic crust was completed by the end of the Eocene (Treves, 1984, her Fig. 9; Carmignani et al., 1978, their Fig. 12B).

The overriding plate at this west- to northwest-dipping subduction zone initially included Corsica, Sardinia, Calabria, and southern France (Alvarez et al., 1974; Alvarez, 1976). During the early to middle Oligocene, rifting in the northern Balearic Basin [5] began to separate a continental fragment that included Corsica/Sardinia/Calabria from southern France (Biju-Duval et al., 1978; Burrus et al., 1984; Cherchi and Montadert, 1982), presumably by backarc spreading above the northwest-dipping subduction zone. Calc-alkaline volcanics (Savelli et al., 1979) erupted above this subduction zone in western Sardinia, beginning at $29 \mathrm{Ma}$ (late Oligocene). 
A

(m) 100

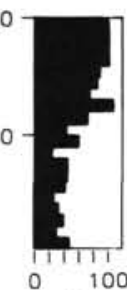

0

100

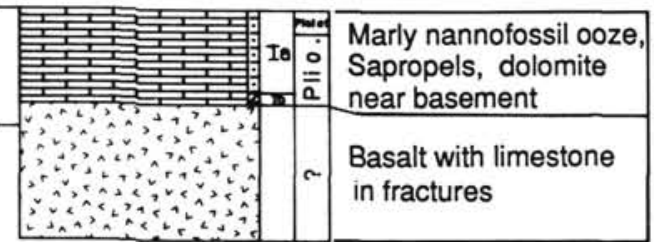

B

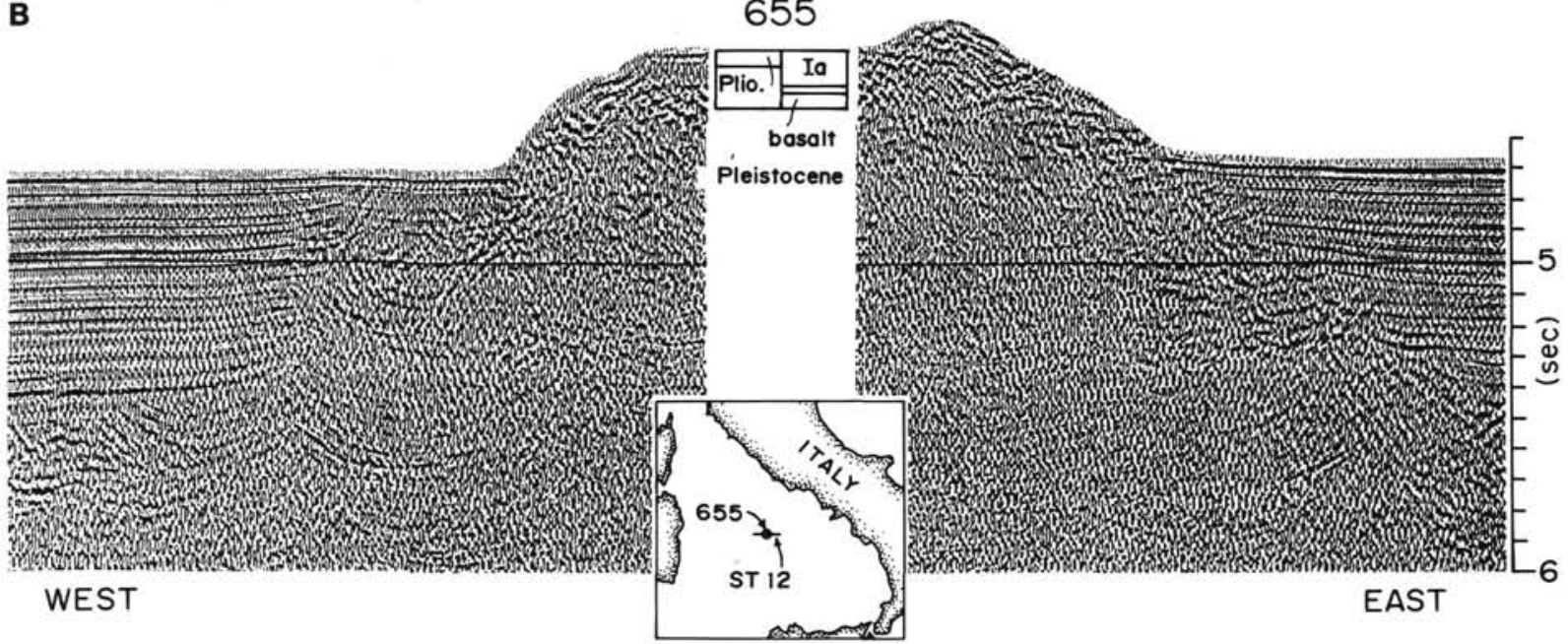

Figure 7. A. Core log showing the lithologic units recovered at Site 655 . The recovery of $120 \mathrm{~m}$ of basalt flows narrows the position of the boundary between continental and basaltic crust to the $25-\mathrm{km}$-wide gap between this site and the de Marchi seamount. B. Seismic reflection profile showing the location of Site 655 on the crest of a north-south trending ridge near the transition from basaltic to continental crust.

A
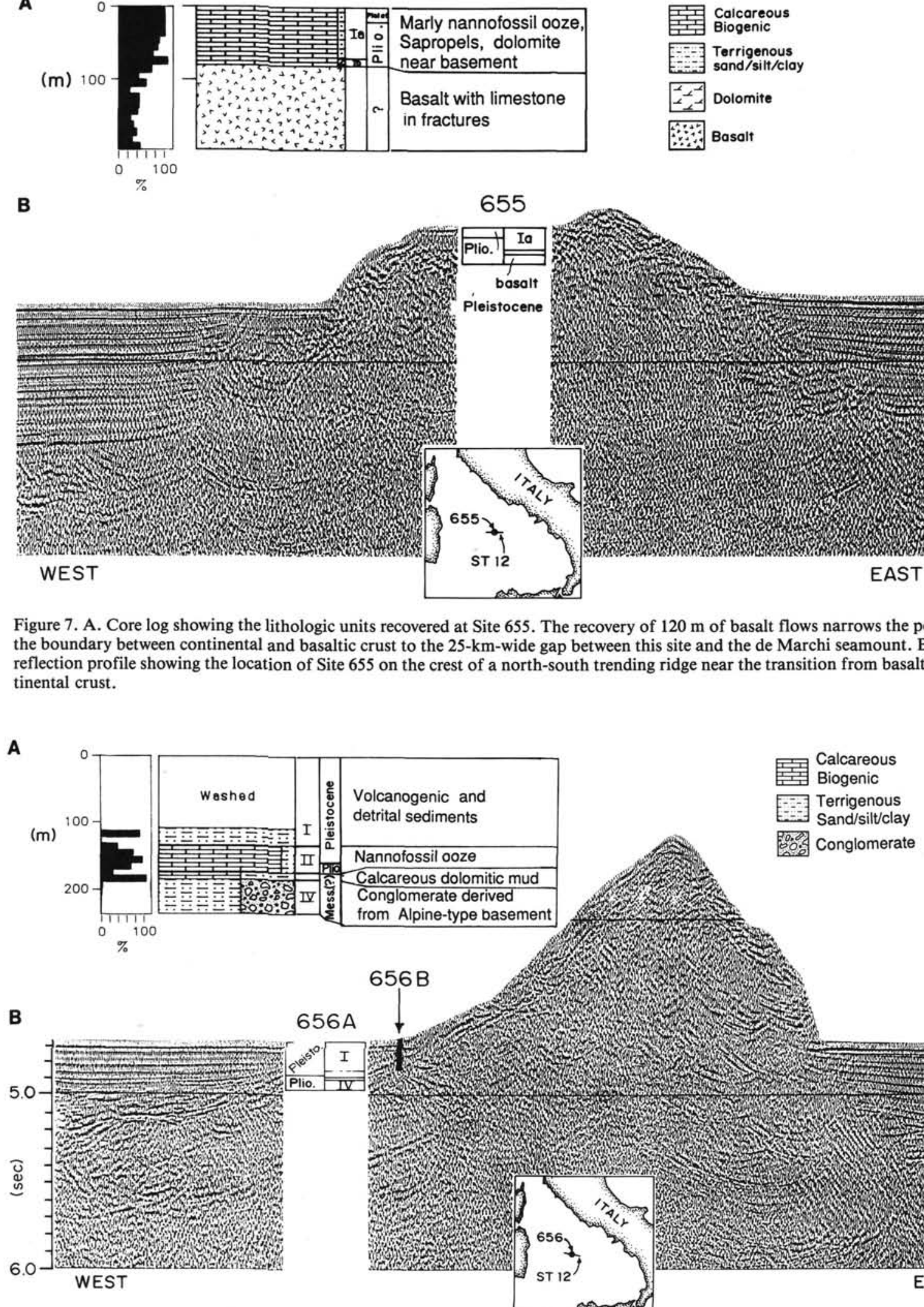
5 


\section{Miocene}

\section{Early to Middle Miocene}

Rifting in the northern Balearic Sea gave way to seafloor spreading in the early Miocene (Aquitanian or lower Burdigalian) [6], accompanied by a $30^{\circ}$ counterclockwise rotation of Sardinia (Montigny et al., 1981). Seafloor spreading ceased in the northern Balearic Sea in the Burdigalian ( 19 Ma) [7]. However, calc-alkaline volcanic eruptions continued on Sardinia (Savelli et al., 1979), suggesting that subduction beneath Sardi$\mathrm{nia} / \mathrm{Corsica} / \mathrm{Calabria}$ continued uninterrupted until at least 13 Ma.

Several lines of reasoning hint that extension of continental lithosphere within the Tyrrhenian may have begun in the early or middle Miocene [8]. The evidence for pre-Tortonian rifting is ambiguous, and the only Leg 107 samples of possible early to middle Miocene age do not help to resolve the question. Two pebbles of polymict sandstone recovered in lithologic Unit IVC of Site 652 (Shipboard Scientific Party, 1987c, p.768, pebbles 7 and 10) have been tentatively assigned to this age by analogy with facies in Calabria (Sartori et al., this volume). The varied clast lithologies, including metamorphic and igneous quartz, calcite, dolomite, low-grade metamorphic lithic fragments, glauconite, dolomite, bryozoans, mollusk fragments, and benthic foraminifers (Sartori et al., this volume), indicate an immature sediment having an orogenic source region, possibly deposited on a continental shelf or slope. In our opinion, the extent of early and/or middle Miocene rifting in the Tyrrhenian remains an open question.

Compressional deformation became widespread around what would become the northeastern, eastern, and southeastern borders of the Tyrrhenian. The transport direction of these compressional folds and faults is consistently away from the present Tyrrhenian, i.e., northeast in the Apennines, south to southeast in Sicily.

\section{Tortonian}

Beginning in the Tortonian, Leg 107 data provide significant constraints on the history of the Tyrrhenian. Whereas until now we have merely attempted to incorporate our sparse Leg 107 clues into a story derived primarily from circum-Tyrrhenian observations, from now on the Leg 107 data drive the story.

\section{Tectonic and Magmatic Processes}

By Tortonian time, rifting appears to have been well underway in the region that is now the upper Sardinian margin. Rifting, in the sense of extension, cannot be observed directly by drilling, but the correlative processes of subsidence and tilting of fault-bounded crustal blocks can be documented. The base of Hole $654 \mathrm{~A}$ records a transgressive sequence evolving upsection from subaerial conglomerate [9] (lithologic Unit VI, Fig. 6 ), to shallow water glauconite-bearing sand (Unit V), to openmarine nannofossil ooze (Unit IV). Benthic foraminifer markers indicate that water depth increased upsection from shallow (lagoonal) to a few hundred meters in the upper part of the nannofossil ooze unit (Shipboard Scientific Party, 1987e, p. 768). Clay mineralogy evolves upsection from an assemblage derived directly from active erosion of fresh crystalline rocks (abundant fresh illite, chlorite, feldspar, and quartz) in lithologic Unit V and the lower part of Unit IV, to an assemblage derived from soil (increased smectite and kaolinite) in the upper part of the nannofossil ooze unit (lithologic Unit IV) (Chamley et al., this volume; Borsetti et al., this volume). Because the base of Hole $654 \mathrm{~A}$ falls within the landward-dipping wedge interpreted as synrift sediments on seismic-reflection profiles (Mascle and Rehault, this volume; also Fig. 6), we attribute the transgression recorded in Units VI, V, and IV to rifting-phase tectonic subsi- dence. In this context, the trend in clay mineralogy suggests that subaerial relief in the regions surrounding the evolving rift became more subdued through time (Chamley et al., this volume).

Normal faulting and subsidence were not confined to the Site 654 fault-block, but rather were widespread around the margins of the Tyrrhenian Sea in the Tortonian [10]. At the same time, compressional thrust-faulting and folding dominated the late Miocene tectonics northeast, east, and southeast of the presentday Tyrrhenian Basin. As in the early to middle Miocene, the transport direction in the compressional zones was radially outward away from the Tyrrhenian. Along any given radial transect across the circum-Tyrrhenian orogenic belts, the locus of most intense compressional deformation tended to migrate outward (away from the Tyrrhenian) with time (Elter et al., 1975; Hill and Haywood, 1988).

A few potassium/argon (K/Ar) dates from DSDP Site 373 in the southeastern Vavilov Basin fall between 6 and $8 \mathrm{Ma}$ (Barberi et al., 1978; Savelli et al., 1978). If these scattered dates are reliable [11], local rift-related vulcanism may have begun in Vavilov Basin during Tortonian time. The Tortonian saw little or no vulcanism in the circum-Tyrrhenian regions, and no Tortonian ash layers were detected in Leg 107 cores (McCoy and Cornell, this volume).

At about $9 \mathrm{Ma}$ (magnetic anomaly 5), the direction of Africa-Eurasia motion changed from nearly north-south to more nearly northwest-southeast (Dewey et al., in press). Under the new plate motion vector, the direction of convergence was more nearly parallel to the inferred dip of the downgoing slab.

\section{Paleoenvironment}

The Tortonian/lower Messinian marls and oozes of Site 654 are among the most thoroughly bioturbated sediments recovered during Leg 107. Organic content is high (average $0.3 \%$ as contrasted with $<0.1 \%$ for Pliocene sediments of the same site) and is derived primarily from marine algae (Emeis, Mycke, and Degens, this volume). Subtropical species of planktonic foraminifers are common (Glacon, Vergnaud Grazzini, et al., this volume). Thus, it seems that prior to the Messinian desiccation, the western Tyrrhenian was a warm, productive, well-ventilated sea.

\section{Messinian $(\sim 6.5$ to $\sim 4.8 \mathrm{Ma})[12]$ \\ Paleoenvironmental and Sedimentary Processes}

During the Messinian age, the passage through which water flowed from the Atlantic to the Mediterranean was greatly restricted by tectonic movements and/or a decrease in sea level (e.g., Hsü et al., 1973). Various exotic lithologies were deposited in and around the entire Mediterranean (e.g., Cita et al., 1978). Evaporites and brackish-water lagoonal facies formed in response to extreme salinity fluctuations in the restricted basin. Enhanced erosion of the newly exposed continental shelf and slope (Ryan and Cita, 1978) led to deposition of voluminous clastics around basin margins.

In Site 654, we have documented the first deep-sea record of the initiation of the salinity crisis. The biostratigraphically defined Tortonian/Messinian boundary [13] does not coincide with the onset of unusual hydrographic conditions. Instead, the contact falls within homogeneous, bioturbated, nannofossil oozes (lithologic Unit IV, Fig. 6). Deposition of nannofossil ooze persisted for several hundred thousand years [14] into the lowermost Messinian. However, elevated $\delta^{18} \mathrm{O}$ values [15] were recorded in some lowermost Messinian samples (Glacon, Vergnaud Grazzini, et al., this volume), suggesting that net evaporation had increased before any lithologic change had yet occurred.

The first lithologic sign of the impending salinity crisis at Site 654 is the abrupt appearance of dark-colored, finely lami- 
nated, dolomitic, organic-rich sediments (lithologic Unit III, Fig. 6) containing radiolarians, sponge spicules, and diatoms. High concentrations of organic carbon [16], abundant pyrite, and lack of burrowing suggest an anoxic environment. Anomalously heavy oxygen-isotope ratios in dolomite samples could indicate substantial evaporation (Pierre and Rouchy, this volume) [17]. Perhaps a slight, preliminary decrease in sea level converted the basin and range topography of the actively rifting margin into an interconnected series of silled basins. Within such basins, circulation would have been inhibited, productivity may have been enhanced, and local anoxia could have developed. The duration of this environment is unknown.

During the late Messinian, evaporites were deposited on the upper Sardinia margin. At both Sites 653 and 654, we recovered intervals dominated by gypsum interbedded with intervals dominated by clay (Kastens, Mascle, Auroux, et al, 1987, second frontispiece, photo D). Similar observations in DSDP Sites 132, 134, 372, 374 (Garrison et al., 1978; Nesteroff, 1973), and in circum-Mediterranean exposures had been interpreted as resulting from periodic evaporative drawdown (gypsum-rich layers) and reflooding with Atlantic-derived waters (Hsü et al., 1978). Leg 107 results strengthen the inference that the evaporitic sediments were derived from marine waters. Planktonic foraminifers and calcareous nannofossils are present in both the clayrich intervals and in thin films within the gypsiferous intervals (Pierre and Rouchy, this volume; C. Müller, this volume; Shipboard Scientific Party, 1987e, Fig. 12). Sulfur and oxygen-isotope values of sulfate minerals overlap the values measured on gypsum from present-day salt pans (Pierre and Rouchy, this volume). However, strontium isotopes of Site 654 gypsum samples are significantly lighter than expected for marine water of Messinian age, which D. Mueller et al. (this volume) attribute to an influx of light-strontium river water into the isolated basin [18]. The stratigraphic interpretation preferred by the shipboard party (Channell et al., this volume) implies that the interval during which evaporites were deposited at Site 654 lasted between 550,000 yr and about $1 \mathrm{Ma}$ [19]. A proposed unconformity within this interval (Channell, Torii, and Hawthorne, this volume) may span the time when halite-bearing "lower evaporites" were deposited elsewhere in the Mediterranean.

The Mediterranean Messinian generally is characterized by significant lateral facies variability, as is seen in modern evaporitic environments. In the Tyrrhenian, where the Messinian regression exposed a complex topography shaped by active tectonics, lateral facies variability is particularly marked (Fabbri and Curzi, 1979; Malinverno et al., 1981). At Site 656, the inferred Messinian [20] sediments are subaerial conglomerates (lithologic Unit IV; Kastens, Mascle, Auroux, et al., 1987, first frontispiece, photo B) and gray dolomitic calcareous mud (lithologic Unit III of Hole 656A).

At Site 652, also on the lower Sardinia margin, the pre-Pliocene sediments comprise thinly bedded sands, silts, and muds, interrupted by a pebble layer at about 340 meters below seafloor (mbsf). The most distinctive and most frustrating characteristic of these sediments is that the entire 532-m-thick section is almost totally lacking in autochtonous fossils. Except for a few organic-rich samples that are likely to have been remagnetized, the pre-Pliocene sediments are reversely magnetized; Channell et al. (this volume) consequently conclude that the entire prePliocene sequence falls within the lowermost reversed polarity interval of the Gilbert chron, i.e., within the upper part of the Messinian stage [21]. Sedimentary structures in the pre-Pliocene sands, silts, and muds of Site 652 indicate subaqueous deposition as turbidites and tempestites. The lack of autochthonous marine fossils implies that Atlantic-derived waters generally did not reach this half-graben during the periodic refloodings of the Mediterranean in the Messinian [22]. Anhydrite is present as millimetric layers or as nodules dispersed throughout the sediment column (Borsetti et al., this volume; Pierre and Rouchy, this volume). Organic carbon is abundant [23], and is of primarily terrigenous origin (Emeis et al., this volume). Extremely light oxygen-isotope values on calcite samples from throughout the pre-Pliocene section [24] suggest that the Site 652 basin was fed in large part by fluvial waters during the Messinian. A plausible environment of deposition would be an inward-draining (endoreic) lake (Robertson, this volume). Broglia et al. (this volume) infer that the surrounding region underwent arid/less arid cycles that have been recorded in downhole logs as alternations between fine-grained, $\mathrm{SiO}_{2}$-rich intervals and coarse-grained, $\mathrm{CaCO}_{3}$-rich intervals [25]. Occasional temporary incursions of marine waters may have reached the basin to deposit sparse, small-sized foraminifers (Cita et al., this volume) and sulfate nodules and laminae (Pierre and Rouchy, this volume) [26].

\section{Tectonic and Magmatic Processes}

Rifting, extension, and subsidence continued on the Sardinia margin in the Messinian. Numerous microfaults in the finely laminated sediments of Site 654 lithologic Units III and IV and Site 652 lithologic Units IV and V (Kastens, Mascle, Auroux, et al., 1987, second frontispiece, photo D; Shipboard Scientific Party, 1987e, p.763, Fig. 15) attest to intense tectonic activity during this time span.

On the lower Sardinia margin, the Site 652 fault-block apparently began to tilt during the Messinian; the base of the landward-dipping wedge of seismic reflectors that is interpreted as synrift sediments falls within the barren, pre-Pliocene section (Mascle and Rehault, this volume; Kastens, Mascle, et al., 1988). Several lines of evidence suggest active subsidence and high heat flow on the lower margin during the Messinian. First, Site 652 Messinian sediments fine upsection, as would be expected in a gradually deepening and broadening basin [27]. Second, the extremely rapid clastic sedimentation rate (on the order of $1 \mathrm{~km} / \mathrm{m} . \mathrm{y}$.) that is seen in the Messinian of Site 652 is most readily accommodated in a subsiding basin. Third, Emeis et al. (this volume) conclude that the organic carbon of the Site 652 Messinian sediments is far more thermally mature than either the Pliocene-Pleistocene sediments at the same hole or any of the sediments at Site 654. Finally, Chamley et al. (this volume) and Broglia et al. (this volume) interpret trends in clay mineral abundances [28] as indicative of diagenesis under the influence of high temperatures [29].

Toward the end of the Messinian, tilting of the fault-block on which Site 654 is located may have slowed or stopped. This inference is based on the age of the upper contact of the landward-dipping wedge of seismic reflectors that is interpreted as synrift sediments (Mascle and Rehault, this volume; Kastens, Mascle, et al., 1988). Tilting of the Site 652 fault-block may have continued unabated throughout the Messinian: the inferred synrift/postrift contact on seismic profiles crossing Site 652 lies within the Pliocene section (Mascle and Rehault, this volume; Kastens, Mascle, et al., 1988) [30].

There is little direct evidence for Messinian age vulcanism within the Vavilov or Marsili basins (see also note [11]), although vulcanism in the circum-Tyrrhenian region was active at this time [31]. Messinian sediments of Site 654 contain three tephra layers (McCoy and Cornell, this volume) whose source has not yet been identified.

In the circum-Tyrrhenian orogenic belts, the compressional front migrated farther outward, i.e., northeastward in the Apennines, south to southeast in Sicily. On the western side of the northern Apennines a new tectonic style began to develop, characterized by extensional normal faults striking roughly parallel to the preexisting fabric of the mountain chain (Lavecchia, 1988). 


\section{Transition from Messinian Desiccated Environment to Pliocene Open-Marine Environment}

In much of the Mediterranean and circum-Mediterranean, the terminal part of the Messinian event is characterized by a brackish, shallow-water fauna, including the ostracode Cyprideis pannonica agrigentina and the benthic foraminifer Ammonia beccarii tepida (Cita et al., this volume and references therein), often in a dolomite-rich host rock [32]. Before Leg 107, evidence for Lago-mare facies in the western Mediterranean was equivocal (Hsü et al., 1978, p. 1074); we have now documented the Lago-mare faunal assemblage in the uppermost Messinian of Site 654 (Shipboard Scientific Party, 1987e, p. 767; Cita et al., this volume), and dolomitic mud in the uppermost pre-Pliocene of Site 656 (lithologic Unit III) [33]. The Lago-mare facies records a drastic change in hydrographic budget from a situation in which evaporation exceeded runoff and rainfall to one in which fresh and/or brackish influx exceeded evaporative loss. Hsü et al. (1978) attribute this change to the establishment of a drainage system tapping the vast brackishwater-filled "Paratethys Basins" that lay north of the eastern Mediterranean. The details of such a drainage system remain to be worked out; Leg 107 observations provide a new constraint in that the Paratethyan outflow would have to reach the Tyrrhenian as well as the eastern Mediterranean seas.

The Miocene/Pliocene boundary in the Mediterranean is defined by the resumption of normal marine conditions following the Messinian salinity crisis. Previous investigators (e.g., Cita et al., 1978; Hsü et al., 1973) emphasized the rapidity with which the unusual hydrologic regime of the Mediterranean Messinian sediments gave way to a normal marine environment represented by lower Pliocene "Trubi" marls. Leg 107 results confirm this observation and reveal additional details about how, and possibly why, the transition occurred. The Pliocene magnetostratigraphy worked out by Channell et al. (this volume) places the Messinian/Pliocene boundary at 4.8 Ma (see also note [12]). This date places the reflooding of the Mediterranean at the end of a brief glacial interval (Keigwin, 1987), presumably during a world-wide eustatic increase in sea level. McKenzie and Sprovieri (this volume) and McKenzie et al. (1988) propose that the post-glacial increase in the sea level of the Atlantic increased the rate of influx of seawater into the Mediterranean sufficiently to shift the hydrologic balance out of the evaporative mode.

On the Sardinia margin, the lowermost Pliocene sediments are conspicuous for their bright red, yellow, and brown coloration (Kastens, Mascle, Auroux, et al., 1987, first frontispiece, photo A; second frontispiece, photo B), and their enrichment in iron and manganese oxides, zinc and lead (de Visser and Chamley, this volume; Robertson, this volume) [34]. The Fe and Mn oxides were probably derived by subaerial weathering on the exposed continental shelf and slope, and then eroded and transported to low-lying basins as sea level rose across the continental margin (Nesteroff, 1973; Cita and Ryan, 1973). The matrix of the inferred Messinian subaerial conglomerate of Site 656 (lithologic Unit IV), which is also enriched in manganese, iron, lead, and zinc (Robertson, this volume), may be typical of the source material washed down into the Tyrrhenian in the post-Messinian flooding event. It is intriguing to note that at Site 654 , the brightly-colored iron- and manganese-enriched sediments distinctly overlie the sediments bearing the "Lago-mare" fauna [35]. This suggests that if indeed a "Lago" existed in the Tyrrhenian toward the end of the Messinian, it was of limited extent in either space and/or time. Had water, brackish or otherwise, filled the Tyrrhenian basin in the latest Messinian, we would expect that the products of subaerial weathering on the continen- tal shelf and slope would have been eroded and transported into the basin at that time rather than during the early Pliocene.

McKenzie and Sprovieri (this volume) have used paleontological and isotopic data to examine the sequence of events by which a normal marine circulation pattern and ecosystem were re-established in the earliest Pliocene. Lack of benthic foraminifers (Thunell et al., this volume; McKenzie and Sprovieri, this volume) and wildly fluctuating carbonate abundances (McKenzie and Sprovieri, this volume) and strontium isotopes (McKenzie, Palmer, and Mueller, this volume) in the lowermost Pliocene suggest that oceanographic conditions were highly unstable immediately following the reflooding. About 30,000 yr [36] postflood, a benthic fauna became established, and carbonate abundances, taken as indicative of planktonic productivity, stabilized. Stable conditions continued until approximately 180,000 yr post-flood. Then, a major upheaval occurred: the diverse benthic fauna disappeared and was replaced by a single cold-water, low-oxygen-tolerant species; surface water cooled; carbonate productivity plummeted; and an abnormal surface-to-seafloor oxygen isotopic gradient was established. McKenzie and Sprovieri (this volume) tentatively attribute this upheaval to a catastrophic collapse of the Gibraltar sill, which allowed cold, poorly-oxygenated, Atlantic bottom water to flood into the deep Mediterranean. At this time, the Gibraltar Arc was a focus for dextral transpressive motion between Africa and Eurasia (Platt and Vissers, 1989), and it is conceivable that the Atlantic/Mediterranean dam could have failed along an east-west trending strike-slip fault. The sill between the Balearic and the Tyrrhenian Sea, or sills within the Tyrrhenian, could also have influenced water flow patterns. By 240,000 yr post-flood (early in biozone MPl-2), the crisis was over, carbonate productivity was as high (McKenzie and Sprovieri, this volume) or higher (Thunell et al., this volume) than before, and a benthic fauna indicative of normal oxygen levels was re-established (McKenzie and Sprovieri, this volume).

\section{Pliocene (4.8-1.7 Ma)}

\section{Paleoenvironmental and Sedimentary Processes}

Following the initial upheavals of the post-Messinian re-flooding, the Tyrrhenian Sea settled down to a period of placid hemipelagic sedimentation. Water temperature cooled, presaging the upcoming late Pliocene climatic deterioration. Salinity increased, leading to establishment of the modern anti-estuarine circulation pattern. Throughout the Pliocene/Pleistocene, the Tyrrhenian Sea responded to major global oceanographic and climatic events; however, additional events, not seen in the open ocean, have been recorded as well. What combination of local tectonic, orographic, climatic, and circulatory forces caused these local shifts in stable isotopes and faunal distribution remains an open question.

In common with the rest of the world, the Tyrrhenian Sea experienced overall cooling of surface waters throughout the Pliocene and into the Pleistocene. This cooling trend seems to have been stepwise, rather than continuous. The first major step, at 4.1 to $3.8 \mathrm{Ma}$, caused a shift in both the nannofossil and planktonic foraminiferal assemblages from warm species to warm/ temperate species (Rio, Sprovieri, et al., this volume). The next step, recorded in both the fossil record and in oxygen isotopes, coincided with a cooling of the world's oceans at 3.2 to $3.0 \mathrm{Ma}$ (Thunell et al. and Vergnaud Grazzini et al., this volume; Mueller et al., this volume; Rio, Spovieri, et al., this volume). The onset of Northern Hemisphere glaciation at about 2.4 to $2.7 \mathrm{Ma}$ was marked by an increase in oxygen isotope ratios of planktonic foraminifers (Thunell et al. and Vergnaud Grazzini et al., 
this volume), but no major faunal turnover. Another conspicuous decrease in surface-water temperature occurred at the Pliocene/Pleistocene boundary; this shift is NOT recorded in the open ocean (Thunell et al., this volume; Vergnaud Grazzini et al., this volume).

Today, circulation within the Mediterranean Sea follows an anti-estuarine or lagoonal pattern: Atlantic water flows eastward through the Straits of Gibraltar at shallow depths; an excess of evaporation over precipitation and runoff increases the salinity within the Mediterranean; this denser, saltier water sinks and flows westward across the seafloor of the Gibraltar sill. In the early Pliocene, the circulation pattern through Gibraltar seems to have been just the opposite: eastward flow of denser water at depth and westward flow of less saline water at the surface (Thunell et al., 1987; Rio, Sprovieri, et al., this volume) [37]. Because the outflowing salty tongue of Mediterranean water could potentially influence the circulation of the entire North Atlantic (Reid, 1979), the timing of the establishment of the Mediterranean's anti-estuarine circulation pattern is an important component of world paleocirculation models. Leg 107 results provide some new clues, but do not conclusively answer the question. An increase in evaporation or a decrease in runoff plus rainfall should favor development of an anti-estuarine circulation pattern; the same increase in evaporation or decrease in runoff should shift the oxygen isotope ratio of surface waters toward heavier values. By comparing the oxygen isotope records of Mediterranean and extra-Mediterranean cores, VergnaudGrazzini et al. (this volume) conclude that the hydrographic balance began to favor evaporation over precipitation plus runoff approximately 3.1 to $2.5 \mathrm{Ma}$. They propose that establishment of the anti-estuarine circulation followed a dramatic decrease in rainfall over Europe that was tied to the onset of major Northern Hemisphere glaciation about $2.5 \mathrm{Ma}$ [38]. In contrast, $\mathrm{Ha}$ segawa et al. (this volume) suggest a much more recent (Pleistocene) date for establishing the Mediterranean anti-estuarine circulation pattern. Their reasoning is based on the observation that benthic foraminifers characteristic of the cool waters of the North Atlantic Deep Water mass (NADW) were abundant in the Tyrrhenian in the late Pliocene and earliest Pleistocene [39].

In the latest Pliocene (after $2 \mathrm{Ma}$ ), the first sapropels and sapropelitic layers were deposited in Sites 651, 652. and 655 (Kastens, Mascle, Auroux, et al., 1987). These distinctive, discrete organic-rich strata are more characteristic of the Pleistocene and are discussed in that section of the chapter.

\section{Tectonic and Magmatic Processes}

As Selli and Fabbri pointed out in their prescient 1971 study, the Pliocene was characterized by marked subsidence on the circum-Tyrrhenian margins. Benthic faunal assemblages suggest that Sites 653 and 654 on the upper Sardinia margin were at lower epibathyal depths (800-1200 m water depth) in the early Pliocene [40] and gradually subsided to approximately a water depth of $2000 \mathrm{~m}$ at the Pliocene/Pleistocene boundary (Colalongo et al., this volume; Hasegawa et al., this volume). At Site 652 on the lower Sardinia margin, the synrift/postrift transition (as inferred from seismic stratigraphy) falls within the Pliocene section. Seismic stratigraphy, without direct well control, suggests that dramatic Pliocene subsidence occurred on the Sicilian margin and the margin of penninsular Italy, as well as on the Sardinian margin [41].

Basaltic crust formation in the Tyrrhenian was widespread during the Pliocene [42]. In the vicinity of Site 651, basaltic vulcanism was a multistage process: a layer of basalt flows was erupted (basement Unit 1), and covered with sediment, then a second layer of flows erupted (basement Unit 3), and finally, a doleritic sill intruded into the sediment layer (basement Unit 2)
(Shipboard Scientific Party, 1987b), where it metamorphosed both the sediments and the older basalt flows (Beccaluva et al., this volume). Vavilov and Magnaghi volcanos erupted during the late Pliocene [43] (Savelli, 1988). The available timing constraints suggest that the large central volcanos of Vavilov Basin were built after the bulk of the low-standing basaltic crust of the basin had been emplaced, possibly after cessation of a similar seafloor-spreading tectonic regime (Kastens, Mascle, et al., 1988).

As is common in backarc basins within continental crust, Vavilov Basin basalts span a range of chemistry. At Site 655, a homogeneous stack of transitional mid-ocean ridge basalt (TMORB) flows was recovered (Beccaluva et al., this volume). The older basalt flows at Site 651 are alkalic, whereas younger basalt flows from the same hole have calc-alkaline affinities (Beccaluva et al., this volume). The mantle from which the Site 651 basalts derived may have contained fluids released from the subducting slab beneath the Tyrrhenian (Bertrand et al., this volume) [44]. At Site 373, two different basalt suites were sampled: low-titanium samples similar to high-aluminum abyssal tholeiites (Dietrich et al., 1978) and interbedded with high titanium samples similar to the Site 655 tholeiites (Beccaluva et al., this volume). Finally, Vavilov and Magnagi seamounts have erupted alkalic (Robin et al., 1987) to tholeiitic basalts (Savelli, 1988).

In Marsili Basin, basaltic crust formation began later, toward the end of the Pliocene at approximately $2 \mathrm{Ma}$ (Shipboard Scientific Party, 1987a). The Marsili Basin basalt of Site 650 is highly altered but appears to have calc-alkaline affinities (Beccaluva et al., this volume). The marked vesicularity of the basalt (Shipboard Scientific Party, 1987a, p.147) has been considered evidence that this basin erupted at a shallower depth than the present $4100 \mathrm{~m}$ below sea level (mbsl) (Kastens, Mascle, et al., 1988).

Somewhat surprisingly, we recovered only one tephra layer in Pliocene sediments, as opposed to 80 tephra layers in the Pleistocene (McCoy and Cornell, this volume) [45]. This lone tephra layer was located at Site 655 and was too badly altered to fingerprint its source geochemically. During the Pliocene, subalkalic and alkalic basaltic volcanism was widespread on Sardinia (Beccaluva et al., 1977). A thin $(\sim 2 \mathrm{~m})$ basalt flow was cored within the sediment column of Site 654 just below the Pliocene-Pleistocene boundary. The petrochemistry of this basalt, an intraplate tholeiite, resembles that of the coeval Sardinia volcanics (Beccaluva et al. this volume). The geodynamic relationship, if any, between Tyrrhenian spreading and the intraplate type vulcanism of Sardinia and Site 654 is unknown.

Sometime during or before the early Pliocene, a body of peridotite was emplaced into the crust around Site 651 [46]. Bonatti et al. (this volume) have argued that the peridotite is refractory upper mantle material left behind following one or more episodes of partial melting in a volatile-rich environment. The asthenospheric wedge above a subducting slab might provide an appropriately volatile-rich environment, and the peridotites might be residual mantle material from which island arc [47] and/or backarc basin calc-alkaline basalts were melted out.

After volcanism ceased and sedimentation began, circulation of seawater through the basalt leached calcium and magnesium (Beccaluva et al., this volume) and led to the dolomitization of the lowest part of the sediment column at Sites 650, 651, and 655. The peridotite of Site 651 served as an additional source of magnesium (Robertson, this volume), so that the dolomitized layer there is an order of magnitude thicker than at the other sites. Oxygen isotopes in the sediment (McKenzie, Isern, et al., this volume) and the nature of alteration products within the basalt (Beccaluva et al., this volume) indicate that basalt/seawater interaction and dolomitization occurred at low temperatures $\left(<70^{\circ} \mathrm{C}\right)$. 


\section{Quaternary ( 1.7-0 Ma)}

\section{Sedimentary and Environmental Processes}

Within the Tyrrhenian, the Pleistocene brought two new developments that were superimposed on the placid hemipelagic sedimentation regime that had begun in the Pliocene. First, the extreme glacial/interglacial fluctuations of climate and sea level influenced faunal distributions, productivity, and watermass properties within the Tyrrhenian, as well as processes of erosion and weathering in the surrounding watershed. Second, with the emergence of the Eolian volcanic arc, volcaniclastic material became a major factor in the sediment budget of the southeastern Tyrrhenian.

Glacial/interglacial cycles, as reflected in oxygen isotope ratios and faunal assemblages, intensified during the Pleistocene. At 800,000 to $950,000 \mathrm{yr}$ ago, the average oxygen isotope value of planktonic foraminifers increased (Thunell et al., this volume; Vergnaud Grazzini et al., this volume), a cold-water assemblage began to dominate the planktonic fauna (Glacon, Rio, and Sprovieri, this volume), and the nannoplankton assemblage became less homogeneous (Mueller, this volume). In the watersheds feeding the Tyrrhenian Sea, climate cooled, leading to an increase in irregular, mixed-layer clays relative to chlorite and illite (de Visser and Chamley, this volume). At the same time, the amplitude of the glacial/interglacial oxygen isotope fluctuations increased from less than $1 \%$ to greater than $1.5 \%$ [48] (Thunell et al., this volume; Vergnaud Grazzini et al., this volume). A similar phenomenon in open-ocean oxygen is attributed to increased glacial ice volume associated with a change from a dominant 41,000 -yr periodicity to a 100,000 -yr periodicity (Thunell et al., this volume; Ruddiman and McIntyre, 1986). Another more subtle increase in average $\delta^{18} \mathrm{O}$ and in glacial/interglacial variability may have occurred at about $400,000 \mathrm{yr}$ ago (Rio, Sprovieri et al., this volume; Vergnaud Grazzini et al., this volume).

Discrete layers a few centimeters thick having anomalously high organic carbon content were scattered throughout the uppermost Pliocene and Pleistocene (Kastens, Mascle, Auroux, et al., 1987). The origin of these sapropels and sapropelic layers remains controversial. A general Pleistocene decrease in bottom-water oxygen content, suggested by the abundance of lowoxygen-tolerant benthic fauna (Hasegawa et al., this volume; Sprovieri, Colalongo, et al., this volume), created an environment conducive to preservation of organic carbon. But since sapropels make up at most a few percent of the sediment column, some specific triggering mechanism must have rapidly (but temporarily) caused an increase in production and/or preservation of organic carbon during sapropel events. Mukhopadhyay et al. (this volume) and Brosse and Herbin (this volume) show that the organic matter in sapropels is a mixture of marine and terrestrial material; on this basis, Mukhopadhyay et al. argue that Tyrrhenian sapropels were caused, at least in part, by increased productivity following increased influx of nutrients from runoff and rivers. Sapropels have low $\delta^{18} \mathrm{O}$ values (Thunell et al., this volume), and some are rich in Braarudosphaera bigelowi (Mueller, this volume). The latter observations suggest that evaporation decreased and/or influx of freshwater increased during sapropel formation. Decreased salinity is compatible with the hypothesis, previously advanced for the eastern Mediterranean, that a surficial layer of low-density, low-salinity water inhibited vertical circulation, leading to bottom-water anoxia and enhanced preservation of organic carbon (Thunnell et al., this volume, and references therein).

The rate of influx of tephras and volcaniclastic turbidites increased dramatically in the Pleistocene (Hieke et al., this volume; McCoy and Cornell, this volume; de Visser and Chamley, this volume). One huge volcaniclastic turbidite/debris flow is more than $20 \mathrm{~m}$ thick and can be identified at two sites located $130 \mathrm{~km}$ apart (Sites 650 and 651; McCoy and Cornell, this volume). Some individual volcaniclastic-rich layers are remarkably indurated for their young age, apparently the result of low-temperature alteration of fine-grained basaltic detritus to smectite (Allouc and Champetier, this volume). Where a source area can be identified, Leg 107 volcaniclastic material was derived from either the calc-alkaline and shoshonitic volcanos of the Eolian arc or from the potassium-rich volcanic provinces along the western-central Italian peninsula (McCoy and Cornell, this volume). The increase in volcaniclastic influx presumably reflects the activation and emergence above sea level of the parent volcanos during the Pleistocene. Glacial/interglacial fluctuations in sea level may also have increased the efficiency of transport of turbidity currents to the basins (Shanmugan and Moiola, 1982) [49].

\section{Tectonic and Magmatic Processes}

On the upper Sardinia margin, subsidence had slowed or stopped by Pleistocene time; benthic foraminiferal assemblages at Site 654 indicate water depths at or deeper than $2000 \mathrm{~m}$ throughout the Pleistocene (Colalongo et al., this volume). Instead, Pleistocene tectonic and magmatic activity was focused in the eastern end of the Tyrrhenian, in and around the Marsili Basin. Marsili Basin grew by horizontal extension toward the eastsoutheast [50], at a rate on the order of 3 to $4 \mathrm{~cm} / \mathrm{yr}$ [51]. The basin floor subsided rapidly, probably in excess of $700 \mathrm{~m} / \mathrm{m} . \mathrm{y}$. [52]. The Marsili volcano grew to dominate the basin, erupting tholeiitic basalts early in its history and capping them off with calc-alkaline basalt near its summit (Selli et al., 1977; Savelli, 1988).

Pleistocene vulcanic activity was widespread. The calc-alkaline and shoshonitic Eolian Island volcanic arc is generally considered to be primarily a Pleistocene construction (Beccaluva et al., 1985) [53]. The volcanic fields near Rome and Naples began erupting a distinctive suite of potassium-rich magmas, while Mt. Etna on Sicily erupted alkaline magmas (Savelli, 1988). Elsewhere in the Tyrrhenian, eruptions continued on Vavilov volcano well into the Pleistocene [54].

\section{SIGNIFICANCE OF LEG 107}

Leg 107 shipboard and shore-based studies have tackled a wide range of interrelated problems in tectonics, paleoceanography, paleoclimatology, and sedimentology. Some of our more significant findings and tantalizing questions include the following:

\section{Sedimentation Processes}

1. Intriguingly, Leg 107 cores and well logs show evidence for cyclic sedimentation processes from the Messinian through the Pleistocene, at time scales that hint at ultimate climatic control. In the inferred Messinian lacustrine sediments of Site 652, Broglia et al. (this volume) see silica-rich/carbonate-rich cycles that they attribute to arid/humid cycles in the watershed of the endoreic lake. The Messinian sediments of Site 654 alternate from gypsum-rich units to clay-rich units. Is this alternation controlled by climate within the desiccated Mediterranean, or by the rate of delivery of Atlantic-derived water through the western portal? In the earliest Pliocene record of Site 652, McKenzie and Sprovieri (this volume) document warm/cold cycles, as recorded in oxygen isotopes and species distribution of planktonic foraminifers. In the Pleistocene sediments of Site 650, the abundance of volcaniclastic turbidites may co-vary with glacial/ interglacial cycles recorded in species distribution of planktonic foraminifers. Is this correlation driven by sea-level control of the process by which turbidity currents are triggered? 
2. The recovery of numerous sapropels and sapropelic layers in the Tyrrhenian Sea has reopened the question of what caused the deposition of these distinctive organic-rich layers. Many previously published explanations draw heavily on mechanisms unique to the eastern Mediterranean, such as an influx of freshwater from the Black Sea (e.g., Olausson, 1961; Stanley and Blanpied, 1981) or the Nile (Rossignol-Strick et al., 1982). Most previous investigators (Calvert, 1983, is an exception) invoked enhanced preservation of organic carbon under conditions of bottom-water anoxia. Mukhopadhyay et al. (this volume) argue that the Tyrrhenian sapropels record enhanced productivity. Thunell et al. (this volume) see evidence for a low-salinity surface layer in the low $\delta^{18} \mathrm{O}$ of the sapropels. In fact, a combination of increased productivity and density-stratification of the water body may be required to produce a sapropel (Jenkins and Williams, 1984).

\section{Paleoceanography}

3. Leg 107 data suggest the present anti-estuarine circulation pattern of the Mediterranean was established in the late Pliocene. Previously, an estuarine circulation pattern brought more saline water into the Mediterranean along the seafloor and less saline water out of the Mediterranean along the surface. Because the Mediterranean saline tongue potentially influences the North Atlantic circulation pattern, this result is important for global paleoclimatic and paleoceanographic modeling.

\section{Stratigraphy}

4. The most complete early Pliocene section yet documented in the Mediterranean or circum-Mediterranean was recovered at Site 652. Channell et al.'s (this volume) magnetostratigraphic interpretation places this boundary at $4.8 \mathrm{Ma}$ or approximately one-half million years younger than most previous interpretations.

\section{The Messinian Salinity Crisis}

5. Sediments from Site 654 include the first deep-sea record that spans the Messinian and both the Tortonian/Messinian and Messinian/Pliocene boundaries. The onset of unusual hydrographic conditions post-dates the biostratigraphically defined Tortonian/Messinian boundary by several hundred thousand years.

6. The Messinian is represented by a wide variety of lithofacies and paleoenvironments, even within the confined area of our experiment. Laminated gypsum, finely-laminated clays, subaerial conglomerate, and lacustrine turbidites represent differing responses to evaporative drawdown in a tectonically active region of complex topography.

7. Re-establishment of a stable circulation pattern required about $240,000 \mathrm{yr}$ after the initial post-Messinian flooding (McKenzie and Sprovieri, this volume).

\section{Tectonics}

8. The extensional basin of the Tyrrhenian formed within thickened continental crust on the former site of a collisional orogen (Sartori, this volume, and references therein). This coincidence, as well as the juxtaposition of simultaneous extension in the Tyrrhenian and compression in the circum-Tyrrhenian, call to mind models of extensional collapse of overthickened continental lithosphere that have recently been proposed for the Himalayas (England and Houseman, 1988) and the Alboran Sea (Platt and Vissers, 1989).

9. Major rifting probably began in the Tyrrhenian during the Tortonian. The initiation of rifting follows a major change in the direction of Africa-Europe motion from north-northeast to northwest (Dewey et al., in press). As a result of this change, the direction of major plate convergence was more nearly parallel to the direction of dip of the subducting slab, i.e., more nearly orthogonal to the arc. A decrease in obliquity of convergence causes an increase in the component of convergence perpendicular to the trench, which appears to favor the initiation of backarc extension (Fein and Jurdy, 1986).

10. Emplacement of basaltic crust in the western of the two deep basins (Vavilov Basin) occurred earlier than in the eastern basin (Marsili Basin). This has been explained in terms of "rollback" of the hinge zone of the downgoing slab of African crust (Kastens, Mascle, et al., 1988, and references therein).

11. Extension was diachronous across the Sardinia margin, and the rifting phase was completed more quickly than at classic rifted margins in major oceans. Subsidence and rotation of fault-bounded crustal blocks occurred earlier on the upper margin than on the lower margin. This might be explained by asymmetrical development of the passive margin above an eastwarddipping detachment fault or faults driven by rollback of the hinge zone of the subducting slab (Kastens, Mascle, et al., 1988, and references therein).

12. Marsili Basin formed during the latest Pliocene and Pleistocene by a subsidence rate that was much faster than that observed or predicted for young crust formed at an oceanic spreading center. Such rapid subsidence could be a result of the small size of the basin, and consequent short length of the "spreading center." Thermal conduction in the direction perpendicular to the direction of extension of the basin would cool the newly accreted lithosphere more quickly than predicted by the two-dimensional models applied so successfully to midocean ridge systems (Rosencrantz et al., 1988).

13. A shallow body of mantle-derived peridotite lies under a thin basaltic carapace in the Vavilov Basin. This is not a remnant of Alpine ophiolite, but rather may be refractory mantle material from which a calc-alkaline basaltic magma was removed under hydrous conditions (Bonatti et al., this volume). The timing and mechanism of emplacement of the ultramafic body into the shallow crust remain unknown, but unroofing by deeply penetrating detachment faults must be considered a possible contributing factor (Kastens, Mascle, et al., 1988).

\section{ACKNOWLEDGMENTS}

We gratefully acknowledge the hard work and scientific creativity of the staff of Leg 107 of the JOIDES Resolution. Dave Huey, ODP Supervisor of Drilling Operations, deserves special thanks for the success of Site 654, which turned out to be the cornerstone of the Leg 107 story. Gail Peretsman Clement proved indispensable both at sea and in College Station for keeping track of the reams of documentation generated by the leg.

Discussions with numerous colleagues, including the entire Leg 107 Scientific Party, plus A. Barone, H. Chamley, M.B. Cita, B. Corliss, J. Hawkins, M. Helman, K. Jacob, G. Karner, B. Lyons, A. Malinverno, J. Platt, L. Royden, W.B.F. Ryan, B. C. Schreiber, R. Thunell, W. U1lman, C. Wang, R. Wright, and N. Zitellini helped clarify the ideas expressed here. This manuscript or an earlier draft was reviewed by $\mathbf{M}$. Cita, M. Helman, K. Hurst, F. McCoy, J. McKenzie, J.-P. Rehault, W.B.F. Ryan, B. C. Schreiber, R. Thunell, and N. Zitellini. We thank these colleagues for their insightful comments; however, we accept full responsibility for any errors in fact or interpretation that have crept into the manuscript as we stretched our expertise to cover the vast scope of Leg 107 results. KAK particularly wishes to thank Bill Ryan and Maria Cita for a decade of steadfast support for her studies in the Mediterranean. JM wishes to thank his colleagues in the Villefranche Laboratory for their support in Mediterranean research.

Collection of data and samples used in this study was funded by the governments of the United States, France, Great Britain, the Federal Republic of Germany, and Japan. Preparation of this manuscript was supported in part by JOI through the United States Science Activities Committee, by the National Science Foundation (RII-86000385), and by CNRS-ATP ODP (France). This is Lamont-Doherty Geological Observatory Contribution No. 4520 . 


\section{REFERENCES}

Abbate, E., Botolotti, V., and Principi, G., 1980. Apennine ophiolites: a peculiar oceanic crust. Ofioliti. (Spec. Issue Tethyan Ophiolites), $1: 59-96$.

AGIP, 1981. Italia: Carta Magnetica: Anomalie del Campo Megnetico Residuo (scale 1:500,000), Atti. Min., Direz, Espl. Idrocarburi, Met. Appl., Geofis., San Donato, Milano.

Alvarez, W., 1976. A former continuation of the Alps. Geol. Soc. Am. Bull., 87:891-896.

Alvarez, W., Cocozza, T., and Wezel, F. C., 1974. Fragmentation of the Alpine orogenic belt by microplate dispersal. Nature, 248:309-314.

Barberi, F., Bizouard, H., Capaldi, G., et al., 1978. Age and nature of basalts from the Tyrrhenian Abyssal Plain. In Hsü, K., Montadert, L., et al., Init. Repts. DSDP, 42(Pt. 1): Washington, (U.S. Govt. Printing Office), 509-514.

Bard, J. P., Burg, J. P., Matte, P., and Ribeiro, A., 1980. La chaine hercynienne d'Europe occidentale en terms de tectonique des plaques. Proc. 26th Int. Geol. Congr., Coll. 6, Geol. Europe, Paris, 233-246.

Barker, P. F., and Hill, I. A., 1981. Backarc extension in the Scotia Sea. Phil. Trans. Roy. Soc. London, 300A:249-262.

Barone, A., Fabbri, A., Rossi, S. and Sartori, R., 1982. Geological structure and evolution of the marine areas adjacent to the Calabrian Arc. Earth Evolution Sci., 3:207-221.

Bartole, R., Savelli, D., Tramontana, M., and Wezel, F.-C., 1984. Structural and sedimentary features in the Tyrrhenian margin off Campania, southern Italy. Mar. Geol., 55:163-180.

Beccaluva, L., Deriu, M., Macciotta, G., Savelli, C., and Venturelli, G., 1977. Geochronology and magmatic character of the Pliocene-Pleistocene volcanism in Sardinia (Italy). Bull. Volcanol., 40:1-16.

Beccaluva, G., Gabbianelli, G., Lucchini, F., Rossi, R. L., and Savelli, C., 1985. Petrology and $\mathrm{K} / \mathrm{Ar}$ ages of volcanics dredged from the Eolian seamounts: implications for the geodynamic evolution of the southern Tyrrhenian Basin. Earth Planet. Sci. Lett., 74:187-208.

Benson, M. L., 1972. Ostracodes as indicators of threshold depth in the Mediterranean during the Pliocene. In Stanley, D. J. (Ed.), The Mediterranean Sea: A Natural Sedimentation Laboratory: Stroudsburg, PA (Dowd Hutchinson and Ross), 63-73.

Benson, M. L., 1973. Psychrospheric and continental ostracoda from ancient sediments in the floor of the Mediterranean. In Ryan, W.B.F., and Hsü, K. J., et al., Init. Repts. DSDP, 13: Washington (U.S. Govt. Printing Office), 1002-1008.

Berger, A. L., 1978. Long-term variations of caloric insolation resulting from the earth's orbital elements. Quat. Res., 9:139-167.

Berggren, W. A., Kent, D. V., and Van Couvering, J. A., 1985. Cenozoic geochronology. In Snelling, N. J. (Ed.), Geochronology of the Geologic Record. Geol. Soc. (London) Mem., 10:211-260.

Biju-Duval, B., Dercourt, J., and LePichon, X., 1977. From the Tethys Ocean to the Mediterranean Seas: a plate tectonic model of the evolution of the western Alpine system. In (Ed.), Structural History of the Mediterranean Basins: Paris (Editions Technip), 143-164.

Biju-Duval, B., Letouzey, J., and Montadert, L., 1978. Structure and evolution of the Mediterranean basins. In Hsü, K., and Montadert, L., Init. Repts. DSDP, 34: Washington (U.S. Govt. Printing Office), 951-984.

Blanc, P., and Duplessy, J., 1982. The deep-water circulation during the Neogene and the impact of the Messinian salinity crisis. Deep-Sea Res., 29:1391-1414.

Boccaletti, M., Elter, P., and Guazzoni, G., 1971. Plate tectonic models for the development of the western Alps and northern Apennines. Nature Phys. Sci., 234:108-111.

Boillot, G., Montadert, L., Lemoine, M., and Biju-Duval, B., 1984. Les Marges Continentales Actuelles et Fossiles autor de la France: Paris (Masson).

Bourrouilh, R., Cocozza, T., Demange, M., Durand-Delga, M., Gueirard, S., Guitard, G., Julivert, M., Martinez, F. J., Massa, D. Mirouse, R., and Orsini, J. B., 1980. Essai sur l'evolution paleogéographique, structurale et metamorphique du Paleozoique du Sud de la France et de l'Ouest de la Mediterranée. Proc. 26th Int. Geol. Congr., Coll. 6, Geology of Europe, Paris, 159-188.

Bousquet, J.-C., Lanzafame, G., and Paquin, C., 1988. Tectonic stresses and volcanism: in-situ stress measurements and neotectonic investigations in the Etna area (Italy). Tectonophysics, 149:219-231.
Burrus, J., 1984. Contribution to a geodynamic synthesis of the Provençal Basin (northwestern Mediterranean). Mar. Geol., 55:247-269.

Calvert, S. E., 1983. Geochemistry of Pleistocene sapropels and associated sediments from the eastern Mediterranean. Oceanol. Acta, 6: 255-267.

Capaldi, G., Civetta, L., and Gillot, P. Y., 1985. Geochronology of Pliocene-Pleistocene volcanic rocks from southern Italy. Rend. Soc. Ital. Miner. Petrol., 40:25-44.

Carmignani, L., Giglia, G. K., and Kligfield, R., 1978. Structural evolution of the Apuane Alps: an example of continental margin deformation in the northern Apennines, Italy. J. Geol., 86:487-504.

Channell, J.E.T., Catalano, R., and D'Argenio, B., 1980. Palaeomag netism and deformation of the Mesozoic continental margin in Sicily. Tectonophysics, 61:391-407.

Channell, J.E.T., D'Argenio, B., and Horvath, F., 1979. Adria, the African promontory in Mesozoic Mediterranean palaeogeography. Earth Sci. Rev., 15:213-292.

Cherchi, A., and Montadert, L., 1982. Oligocene-Miocene rift of Sardinia and the early history of the western Mediterranean Basin. $\mathrm{Na}$ ture, 298:736-739.

Cita, M. B., Colalongo, M. L., D'Onofrio, S., Iaccarino, S, and Salvatorini, G., 1978. Biostratigraphy of Miocene deep-sea sediments (Sites 372 and 375), with special reference to the Messinian/Pre-Messinian interval, In Hsü, K. J., Montadert, L., et al., Init. Repts. DSDP, 42: Washington (U.S. Govt. Printing Office), 671-685.

Cita, M. B., and Ryan, W.B.F., 1973. Time scale and general synthesis. In Ryan, W.B.F., Hsü, K. J., et al., Init. Repts. DSDP, 13: Washington (U.S. Govt. Printing Office), 1405-1415.

Cita, M. B., Wright, R. C., Ryan, W.B.F., and Longinelli, A., 1978. Messinian Paleoenvironments. In Hsü, K., Montadert, L., et al., Init. Repts. DSDP, 42: Washington (U.S. Govt. Printing Office), 1003-1035.

Cox, A., 1982. Magnetostratigraphic time scale. In Harland, W. B., et al. (Eds.), A Geologic Time Scale: Cambridge (Cambridge Univ. Press), 63-84. Curzi, P., Fabbri, A., and Nanni, T., 1980. The Messinian evaporitic event in the Sardinia Basin area (Tyrrhenian Sea). Mar. Geol., 34:157-170.

Cyrzi, P., Fabbri, A., and Nanni, T., 1980. The Messinian evaporitic event in the Sardonia Basin area (Tyrrhenian Sea). Mar. Geol., 34: $157-170$.

Decima, A., and Wezel, F. C., 1973. Late Miocene evaporites of the central Sicilian Basin, Italy. In Ryan, W.B.F., Hsü, K., et al., Init. Repts. DSDP, 13: Washington (U.S. Govt. Printing Office), 12341240.

De Lange, G. J., and ten Haven, H. L., 1983. Recent sapropel formation in the eastern Mediterranean. Nature, 305:397-398.

Dercourt, J., Zonenshain, L. P., Ricou, L. E., Kasmin, V. G., LePichon, X., Knipper, A. L., Grandjacquet, C., Sbortshikov, I. M., Geyssant, J., Lepvrier, C., Pechersky, D. H., Boulin, J., Sibuet, J.C., Savostin, L. A., Sorokhtin, O., Westphal, M., Bazhenov, M. L., Laver, J. P., and Biju-Duval, B., 1986. Geological evolution of the Tethys belt from the Atlantic to the Pamirs since the Lias. Tectonophysics, 123:241-315.

Dewey, J. F., Helman, M. L., Turco, E., Hutton, D.W.H., and Knott, S. D., in press. Kinematics of the western Mediterranean. In Coward, M. P., Park, R. G., and Dietrich, D. (Eds.), Spec. Publ. Geol. Soc. Am.

Dewey, J. F., Pitman, W. C., III, Ryan, W.B.F., and Bonnin, J., 1973. Plate tectonics and the evolution of the Alpine system. Geol. Soc. Am. Bull, 84:3137-3180.

Dick, H.J.B., 1980. Vesicularity of Shikoku Basin basalt: a possible correlation with the anomalous depth of backarc basins, DSDP Leg 58. In Klein, G., Kobayashi, K., et al., Init. Repts. DSDP, 58: Washington (U.S. Govt. Printing Office), 895-904.

Dietrich, V., 1988. Sense of overthrust shear in the Alpines nappes of Calabria (southern Italy). J. Struct. Geol., 10:373-381.

Dietrich, V., Emmerman, R., Puchelt, H., and Keller, J., 1978. Oceanic basalt from the Tyrrhenian Basin: DSDP Leg 42A, Hole 373A. In Hsü, K., Montadert, L., et al., Init. Repts. DSDP, 42(Pt. 1): Washington (U.S. Govt. Printing Office), 515-530.

Duschenes, J., Sinha, M. C., and Louden, K. E., 1986. A seismic refraction experiment in the Tyrrhenian Sea. Geophys. J. Roy. Astron. Soc., 85:139-160. 
Eldredge, S., Bachtadse V., and Van der Voo, R., 1985. Paleomagnetism and the orocline hypothesis. Tectonophysics, 119:153-179.

Elter, P., Giglia, G., Tongiorgi, M., and Trevisan, L., 1975. Tensional and compressional areas in the recent (Tortonian to present) evolution of the northern Apennines. Boll. Geofis. Teor. Appl., 17:3-18.

England, P. C., and Houseman, G. A., 1988. The mechanics of the Tibetan Plateau. Phil. Trans. Roy. Soc. London, 326:301-320.

Fabbri, A., and Curzi, P., 1979. The Messinian of the Tyrrhenian Sea: seismic evidence and dynamic implications. G. Geol., 43:215-248.

Fabbri, A., Ghisetti, F., and Vezzani, L., 1980. The Peloritani-Calabria Range and the Gioia Basin in the Calabrian Arc (southern Italy): relationships between land and marine data. Geol. Romana, 19:131150.

Fein, J. B., and Jurdy, D. M., 1986. Plate motion controls on backarc spreading. Geophys. Res. Lett., 13:456-459.

Finetti, I., and Del Ben, A., 1986. Geophysical study of the Tyrrhenian opening. Boll. Geofis. Teor. Appl., 28:75-156.

Funiciello, R., Parotto M., and Praturion, A., 1981. Carta Tettonica d'Italia (Scale 1:50,000): Roma (Consiglio Nazionale delle Richerche).

Garrison, R. E., Schreiber, B. C., Bernoulli, D., Fabricius, F. H., Kidd, R. B., and Melières, F., 1978. Sedimentary petrology and structures of Messinian evaporitic sediments in the Mediterranean Sea: DSDP Leg 42. In Hsü, K. J., Montadert, L., et al., Init. Repts. DSDP, 42(Pt. 1): Washington (U.S. Govt. Printing Office), 571-612.

Gill, J. B., 1976. From island arc to oceanic islands: Fiji, southwestern Pacific. Geology, 4:123-126.

Haq, B. U., Hardenbol, J., and Vail, P. R., 1987. Chronology of fluctuating sea levels since the Triassic. Science, 235:1156-1167.

Harland, W. B., Cox, A. V., Llewellyn, P. G., Pickton, C.A.G., Smith, A. G., and Walters, R., 1982. A Geologic Time Scale: Cambridge (Cambridge Univ. Press)

Harris, L. B., 1985. Direction changes in thrusting of the Schistes Lustres in Alpine Corsica. Tectonophysics, 120:37-56.

Hays, J. D., Imbrie, J., and Shackleton, N. J., 1976. Variations in the Earth's orbit: pacemaker of the Ice Ages. Science, 194:1121-1132.

Hill, K. C., and Hayward, A. B., 1988. Structural constraints on the Tertiary plate tectonic evolution of Italy. Mar. Pet. Geol., 5:2-16.

Hsü, K. J., Cita, M. B., and Ryan, W.B.F., 1973. The origin of the Mediterranean evaporites: DSDP. In Ryan, W.B.F., and Hsü, K. J., et al., Init. Repts. DSDP, 12: Washington (U.S. Govt. Printing Office), 1203-1231.

Hsü, K., Montadert, L., Bernoulli, D., Cita, M. B., Erickson, A., Garrison, R. E., Kidd, R. B., Melieres, F., Müller C., and Wright, R., 1978. History of the Mediterranean salinity crisis: DSDP. In Hsü, K., and Montadert, L., et al., Init. Repts. DSDP, 42(Pt. 1): Washington (U.S. Govt. Printing Office), 1053-1078.

Hussong, D. M., and Uyeda, S., 1982. Tectonic processes and the history of the Mariana Arc: A synthesis of the results of Deep Sea Drilling Project Leg 60. In Hussong, D. M., Uyeda, S., et al., Init. Repts. DSDP, 60: Washington (U.S. Govt. Printing Office), 909929.

Jenkins, J. A., and Williams, D. F., 1984. Nile water as a cause of eastern Mediterranean sapropel formation: evidence for and against. Mar. Micropaleontol., 8:521-534.

Jones, J. G., 1969. Pillow lavas as depth indicators. Am. J. Sci., 267: 181-195.

Karig, D. E., 1974. Evolution of arc systems in the western Pacific. Annu. Rev. Earth Planet. Sci., 2:51-74.

1983. Temporal relationships between backarc basin formation and arc volcanism with special reference to the Philippine Sea. In Hayes, D. E. (Ed.), The Tectonic and Geological Evolution of Southeast Asian Seas and Islands: Part 2. Am. Geophys. Un. Geophys. Mono., 27:318-325.

Kastens, K. A., 1988. The case for asymmetrical rifting above a detachment fault in the opening of the Tyrrhenian Sea, central Mediterranean. EOS, 69:465.

Kastens, K. A., Mascle, J., et al., 1987. Proc. ODP, Init. Repts., 107: College Station, TX (Ocean Drilling Program).

1988. ODP Leg 107 in the Tyrrhenian Sea: insights into passive margin and backarc basin evolution. Geol. Soc. Am. Bull., 100: $1140-1156$.

Keigwin, L. D., 1987. Towards a high resolution chronology for latest Miocene paleoceanographic events. Paleoceanography, 2:639-660.

Kelts, K., and McKenzie, J., 1984. A comparison of anoxic dolomite from deep-sea sediments: Quaternary Gulf of California and Messi- nian Tripoli formation of Sicily. In Garrison, R. E., Kastner M., and Donald, H. (Eds.), Dolomites of the Monterey Formation and Other Organic-Rich Units. Pacific Sect. Soc. Econ. Paleontol. Mineral., 41:19-28.

Kidd, R. B, Cita, M. B., and Ryan, W.B.F., 1978. Stratigraphy of eastern Mediterranean sapropel sequences recovered during Leg 42A and their paleoenvironmental significance. In Hsü, K. J., Montadert, L., et al., Init. Repts. DSDP, 42(Pt. 1): Washington (U.S. Govt. Printing Office), 421-443.

Kligfield, R., 1979. The northern Apennines as a collisional orogen. Am. J. Sci., 279:676-691.

Kligfield, R., Hunziker, J., Dallmeyer, R. D., and Schamel, S., 1986. Dating of deformation phases using $\mathrm{K}-\mathrm{Ar}$ and ${ }^{40} \mathrm{Ar} /{ }^{39} \mathrm{Ar}$ techniques: results from the northern Apennines. J. Struc. Geol., 8:781-798.

Knott, S. D, 1987. The Liguride complex of southern Italy-a Cretaceous to Paleogene accretionary wedge. Tectonophysics, 142:217226.

Kreuzer, H., Mohr, M., and Wendt, I., 1978. Potassium-argon age determinations of basalt samples from Leg 42A, Hole 373A, Core 7. In Hsü, K., and Montadert, L., et al., Init. Repts. DSDP, 42(Pt. 1): Washington (U.S. Govt. Printing Office), 531-537.

Kroopnick, P. M., 1985. The distribution of ${ }^{13} \mathrm{C}$ of $\Sigma^{2} \mathrm{CO}_{2}$ in the world oceans. Deep-Sea Res., 32:57-84.

Lavecchia, G., 1988. The Tyrrhenian-Apennines system: structural setting and seismotectogenesis. Tectonophysics, 147:263-296.

Loubere, P., 1987. Changes in mid-depth North Atlantic and Mediterranean circulation during the late Pliocene--isotopic and sedimentological evidence. Mar. Geol., 77:15-38.

Malinverno, A., 1980. Quantitative estimates of age and Messinian paleobathymetry of the Tyrrhenian Sea after seismic reflection, heat flow and geophysical models. Boll. Geofis. Teor. Appl., 23:159-171.

Malinverno, A., Cafiero, M., Ryan, W.B.F., and Cita, M. B., 1981. Distribution of Messinian sediments and erosional surfaces beneath the Tyrrhenian Sea: geodynamic implications. Oceanol. Acta, 4: 489-495.

Malinverno, A. and Ryan, W.B.F., 1986. Extension in the Tyrrhenian Sea and shortening in the Apennines as result of arc migration driven by sinking of the lithosphere. Tectonics, 5:227-245.

Mascle, J., Kastens, K., Auroux C., and Leg 107 Scientific Party, 1988. A landlocked backarc basin: preliminary results from ODP Leg 107 in the Tyrrhenian Sea. Tectonophysics, 146:149-162.

Mauffret, A., Montadert, L., Lavergne, M., and Willm, C., 1978. Geological and geophysical setting of DSDP Site 372 (western Mediterranean), In Hsü, K. J., and Montadert, L., et al., Init. Repts. DSDP, 42: Washington (U.S. Govt. Printing Office), 889-897.

McKenzie, D., 1978. Some remarks on the development of sedimentary basins. Earth Planet. Sci. Lett., 40:25-32.

McKenzie, J. A., Hodell, D. A., Mueller, P. A., and Mueller, D. W., 1988. Application of strontium isotopes to late Miocene-early Pliocene stratigraphy. Geology, in press.

Melieres, F, 1978. Detailed X-ray mineralogy of Core 9, Sections 1 and 2, Hole 372 (Balearic Rise). In Hsü, K. J., Montadert, L., et al., Init. Repts. DSDP, 42(Pt. 1: Washington (U.S. Govt. Printing Office), 385-386.

Montigny, R., Edel, J. B., and Thuizat, R., 1981. Oligo-Miocene rotation of Sardinia, K-Ar dates and paleomagnetic data of Tertiary volcanics. Earth Planet. Sci. Lett., 54:261-271.

Moore, J. G., 1965. Petrology of deep-sea basalts near Hawaii. Am. J. Sci., 263:40-52.

1970. Water content of basalt erupted on the ocean floor Contrib. Mineral. Petrol., 28:272-279.

Moore, J. G., and Schilling, J.-G., 1973. Vesicles, water and sulfur in Reykjanes Ridge basalts. Contrib. Mineral. Petrol., 41:105-118.

Moussat, E., 1983. Evolution de la Mer Tyrrhenienne centrale et orientale et de ses marges septentrionales en relation avec le néotectonique dans l'arc calabrais [Ph.D. dissert.]. Univ. of Pierre and Marie Curie, Paris.

Moussat, E., Rehault, J. P., Fabbri, A., and Mascle, G., 1985. Evolution géologique de la Mer Tyrrhenienne. Comp. Rend. Acad. Sci. Paris, 301(7):491-496.

Mueller, D. W., and Hsü, K. J., 1987. Event stratigraphy and paleoceanography in the Fortuna Basin (southeast Spain): a scenario for the Messinian salinity crisis. Paleoceanography, 2:679-696.

Müller, C., 1985. Late Miocene to Recent Mediterranean biostratigraphy and paleoenvironments based on calcareous nannoplankton. In 
Stanley, D. J., and Wezel, F. C. (Eds.), Geological Evolution of the Mediterranean Basin: New York (Springer-Verlag), 471-485.

Nakamura, K., 1977. Volcanoes as possible indicators of tectonic stress orientation--principle and proposal. J. Volcanol. Geotherm. Res., 2: $1-16$

Nesteroff, W. D., 1973. Mineralogy, petrography, distribution, and origin of the Messinian Mediterranean evaporites, 1973. In Ryan, W.B.F., Hsü, K. J., et al., Init. Repts. DSDP, 13: Washington (U.S. Govt. Printing Office), 673-694.

1973. Distribution of the fine-grained sediment component in the Mediterranean. In Ryan, W.B.F., Hsü, K. J., et al., Init. Repts. DSDP, 13: Washington (U.S. Govt. Printing Office), 666670.

Olausson, E., 1961. Studies in deep-sea cores. Repts. Swedish Deep-Sea Exped., 1947-1948, 8:337-391.

Parsons, B., and Sclater, J. C., 1977. An analysis of ocean floor bathymetry and heat flow with age. J. Geophys. Res., 82:803-827.

Platt, J. P., and Vissers, R.L.M., 1989. Extensional collapse of overthickened continental lithosphere: a new working hypothesis for the Alboran Sea and Gibraltar Arc. Geology, 17:485-594.

Rehault, J. P., Boillot, G., and Mauffret, A., 1984a. The western Mediterranean basin geological evolution. Mar. Geol., 55:447-477.

Rehault, J. P., Mascle, J., and Boillot, G., 1984b. Evolution géodynamique de la Mediterranée depuis l'Oligocene. Mem. Soc. Geol. Ital., 27:85-96.

Rehault, J. P., Mascle, J., Fabbri, A., Moussat, E., and Thommeret, M., 1987a. The Tyrrhenian Sea before Leg 107. In Kastens, K., and Mascle, J., et al., Proc. ODP, Init. Repts., 107: College Station, TX (Ocean Drilling Program), 9-35.

Rehault, J. P., Moussat, E., and Fabbri, A., 1987b. Structural evolution of the Tyrrhenian backarc basin. Mar. Geol., 74:123-150.

Reid, J. L., 1979. On the contribution of Mediterranean Sea outflow to the Norwegian-Greenland Sea. Deep-Sea Res., 26:1199-1223.

Ricou, L. E., Dercourt, J., Geyssant, J., Grandjacquet, C., Lepvrier, C., and Biju-Duval, B., 1986. Geological constraints on the Alpine evolution of the Mediterranean Tethys. Tectonophysics, 123:83-122.

Ritsema, A. R., 1979. Active or passive subduction of the Calabrian Arc. Geol. Mijnb., 58:127-134.

Robertson, A., and Dixon, J. E., 1984. Introduction: aspects of the geological evolution of the eastern Mediterranean. In Dixon, J. E., and Robertson, A.H.F. (Eds.), The Geological Evolution of the Eastern Mediterranean: Oxford (Blackwell Scientific Publications), 1-74.

Robin, C., Colantoni, P., Gennesseaux, M., and Rehault, J. P., 1987. Vavilvov Seamount: a mildly alkaline Quaternary volcano in the Tyrrhenian basin. Mar. Geol., 78:125-136.

Rosencrantz, E., Ross, M. I., and Sclater, J. G., 1988. Age and spreading history of the Cayman Trough as determined from depth, heat flow, and magnetic anomalies. J. Geophys. Res., 93:2141-2157.

Rossignol-Strick, M., Nesteroff, W., Olive, P., and Vergnaud-Grazzini, C., 1982. After the deluge: Mediterranean stagnation and sapropel formation. Nature, 295:105-110.

Ruddiman, W. F., and MacIntyre, A., 1986. Matuyama 41,000 year cycles: North Atlantic Ocean and Northern Hemisphere ice sheets. Earth Planet. Sci. Lett., 80:117-129.

Ryan, W.B.F., Stanley, D. J., Hersey, J. B., Fahlquist, D. A., and Allan, T. D., 1971. The tectonics and geology of the Mediterranean Sea. In Maxwell, A. E. (Ed.), The Sea, Vol. 4: New York (Wiley), 387-492.

Ryan, W.B.F., and Cita, M. B., 1978. The nature and distribution of Messinian erosional surfaces-indicators of a several-kilometer-deep Mediterranean in the Miocene. Mar. Geol., 27:193-230.

Sartori, R., Mascle, G., and Amaufric du Chaffaut, S., 1987. A review of circum-Tyrrhenian regional geology. In Kastens, K., Mascle, J., et al., Proc. ODP, Init. Repts., 107: College Station, TX (Ocean Drilling Program), 37-63.

Saunders, A. D., and Tarney, J., 1979. The geochemistry of basalts from a backarc spreading center in the east Scotia Sea. Geochim. Cosmochim. Acta, 43:555-572.

Savelli, C., 1988. Late Oligocene to Recent episodes of magmatism in and around the Tyrrhenian Sea: implication for the processes of opening in a young interarc basin of intra-orogenic (Mediterranean) type. Tectonophysics, 146:163-181.

Savelli, C., Beccaluva, L., Deriu, M., Macciotta, G., and Maccioni, L., 1979. K/Ar geochronology and evolution of the Tertiary "calc-alkalic" volcanism of Sardinia (Italy). J. Volcanol. Geotherm. Res., 5: 257-269.
Savelli, C., and Lipparini, E., 1978. K/Ar age determinations on basalt rocks from Hole 373A. In Hsü, K., and Montadert, L., et al., Init. Repts. DSDP, 42(Pt. 1): Washington (U.S. Govt. Printing Office), 537-539.

Savostin, L. A., Sibuet, J.-C., Zonenshain, L. P., LePichon, X., and Roulet, M.-J., 1986. Kinematic evolution of the Tethys belt from the Atlantic Ocean to the Pamirs since the Triassic. In Aubouin, J., LePichon, X., and Monin, A. S. (Eds.), Evolution of the Tethys. Tectonophysics, 123:1-35.

Scientific Staff BAN 84-12, 1985. Gypsum precipitation from cold brines in an anoxic basin in the eastern Mediterranean. Nature, 314:152154.

Selli, R., and Fabbri, A., 1971. Tyrrhenian: a Pliocene deep sea. Rend. Classe Sci. Fisch., Mat., Natur., Ser. VII, L:580-592.

Selli, R., Lucchini, F., Rossi, P., Savelli, C., and Del Monte, M., 1977. Data geologici, petrochimici e radiometrici sui volcani centro-tirrenici. G. Geol., 2, 42, 1:221-246.

Sengor, A.M.C., Yilmaz, Y., and Sungurlu, O., 1984. Tectonics of the Mediterranean Cimmerides: nature and evolution of the western termination of Paleo-Tethys. In Dixon, J. E., and Robertson, A.H.F. (Eds.), The Geological Evolution of the Eastern Mediterranean: Oxford (Blackwell Scientific Publ. ), 77-112.

Serri, G., 1980. Chemistry and petrology of gabbroic complexes from the northern Apennine ophiolites. Proc. Int. Ophiolite Symp., Сyprus (Cyprus Geol. Surv. Dept.), 296-313.

Shanmugan, G., and Moiola, R. J., 1982. Eustatic control of turbidites and winnowed turbidites. Geology, 10:231-235.

Shipboard Scientific Party, 1978. Site 372: Menorca Rise. In Hsü, K. J., Montadert, L., et al., Init. Repts. DSDP, 42: Washington (U.S. Govt. Printing Office), 59-150.

Shipboard Scientific Party, 1987a. Site 650. In Kastens, K. A., Mascle, J., Auroux, C., et al., Proc. ODP, Init. Repts., 107: College Station, TX (Ocean Drilling Program), 129-285.

Shipboard Scientific Party, 1987b. Site 651. In Kastens, K. A., Mascle, J., Auroux, C., et al., Proc. ODP, Init. Repts., 107: College Station, TX (Ocean Drilling Program), 287-401.

Shipboard Scientific Party, 1987c. Site 652. In Kastens, K. A., Mascle, J., Auroux, C., et al., Proc. ODP, Init. Repts., 107: College Station, TX (Ocean Drilling Program, 403-597.

Shipboard Scientific Party, 1987d. Site 653. In Kastens, K. A., Mascle, J., Auroux, C., et al., Proc. ODP, Init. Repts., 107: College Station, TX (Ocean Drilling Program), 599-745.

Shipboard Scientific Party, 1987e. Site 654. In Kastens, K. A., Mascle, J., Auroux, C., et al., Proc. ODP, Init. Repts., 107: College Station, TX (Ocean Drilling Program), 747-875.

Shipboard Scientific Party, 1987f. Site 655. In Kastens, K. A., Mascle, J., Auroux, C., et al., Proc. ODP, Init. Repts., 107: College Station, TX (Ocean Drilling Program), 877-949.

Shipboard Scientific Party, 1987g. Site 656. In Kastens, K. A., Mascle, J., Auroux, C., et al., Proc. ODP, Init. Repts., 107: College Station, TX (Ocean Drilling Program), 951-999.

Stanley, D. J., and Blanpied, C., 1981. Late Quaternary water exchange between eastern Mediterranean and the Black Sea. Nature, 285:537541.

Suc, J. P., 1984. Origin and evolution of the Mediterranean vegetation and climate in Europe. Nature, 307:429-432.

Suess, H. E., 1980. The radiocarbon record in tree rings of the last 8,000 years. Radiocarbon J., 22:200-209.

Thunell, R. C., Williams, D. F., and Howell, M., 1987. Atlantic-Mediterranean water exchange during the late Neogene. Paleoceanography, 2:661-678.

Thunell, R. C., and Williams, D. F., 1983. The stepwise development of Pliocene-Pleistocene paleoclimatic and paleoceanographic conditions in the Mediterranean: oxygen isotopic studies of DSDP Sites 125 and 132. In Meulenkamp, J. E. (Ed.), Reconstruction of Marine Paleoenvironments. Utrecht Micropaleontol. Bull., 30:111-127.

Treves, B., 1984. Orogenic belts as accretionary prisms: the example of the northern Apennines. Ofioliti, 9:577-618.

Tricardi, F., and Zitellini, N., 1987. The rifting of the Tyrrhenian Basin. Geo-Mar. Lett., 7:1-6.

van Harten, D., 1984. A model of estuarine circulation in the Pliocene Mediterranean based on new ostracod evidence. Nature, 312:359361.

Van Wamel, W. A., 1987. On the tectonics of the Ligurian Apennines (northern Italy). Tectonophysics, 142:87-98. 
Vergnaud Grazzini, C., 1985. Mediterranean late Cenozoic stable isotope record: stratigraphic and paleoclimatic implications. In Stanley, D. J., and Wezel, F. C. (Eds.), Geological Evolution of the Mediterranean Basin: New York-Berlin-Hiedelberg (Springer-Verlag), 413451.

Wang, C., Hwang, W., and Shi, Y., 1989. Thermal evolution of a rift basin-the Tyrrhenian Sea. J. Geophys. Res., 4:3991-4006.

Zitellini, N., Trincardi, F., Marani, M., and Fabbri, A., 1986. Neogene tectonics of the northern Tyrrhenian Sea. G. Geol., 48:25-40.

Zwart, H. J., and Dornsiepen, U. F., 1980. The Variscan and pre-Variscan tectonic evolution of central and western Europe: a tentative model. Proc. 26th Int. Geol. Congr. Coll. 6, Geol. of Europe (Paris), 226-232.

Date of initial receipt: 20 September 1988

Date of acceptance: 8 March 1989

Ms 107B-187

\section{APPENDIX \\ Notes}

[1] The hypothesis that much of the Ligurian Tethys crust was formed on short spreading segments near transform faults is based on the following observations of ophiolites in the northern Apennines (Abbate et al., 1980; Serri, 1980): (1) serpentinite is abundant and was apparently locally exposed at the seafloor without an extrusive carapace; (2) the crust is thin; (3) the basalts are highly fractionated; and (4) breccias are abundant. The transform fault scenario is also consistent with the inferred northeast/southwest trend of the ocean (Dercourt et al., 1986, Pl. 2), compared with the sinistral strike-slip sense of Africa/Eurasia motion (Savostin et al., 1986) at this time. The set of observations that led to this transform fault hypothesis is pertinent to Leg 107 because we also recovered abundant serpentinized peridotite (basement Unit 4) and basaltic breccias (basement Units 1 and 3) at Site 651. These similarities between Site 651 and northern Apennine ophiolites led to the shipboard hypothesis that at Site 651 we might have cored into an isolated block of continental crust that happened to contain a sliver of Tethyan ophiolite (Shipboard Scientific Party, 1987b). Bonatti et al. (this volume) argue persuasively against this hypothesis because of major geochemical differences between Site 651 and Apennine peridotites: Ligurian ophiolites contain almost undepleted lherzolites (Abbate et al., 1980 ), whereas at Site 651 we recovered highly depleted harzburgites and dunites.

[2] The direction of dip of the subduction zone, which consumed the Ligurian Tethys during Cretaceous to Paleogene time, is controversial. Dercourt et al. (1986, Pl. 4), Rehault et al.(1984), van Wamel (1987), and Harris (1985) proposed an dip eastward or toward Apulia. Such a model explains the westward-verging ophiolitic nappes on Corsica (Harris, 1985 ) and permits one to infer one continuous subduction zone along the length of Sardinia, Corsica, and the incipient Alpine chain farther north (Dercourt et al., Pl. 4, 1986). Knott (1987) and Dietrich (1988) describe eastward-verging structures, compatible with a westward-dipping subduction zone in the southern Apennines. Dewey et al. (in press, Fig. 5A) incorporated Knott's and Dietrich's evidence into a model having an eastward-dipping paleosubduction zone at the latitude of Corsica, and a westward-dipping subduction zone farther south. Trevers (1984), Abbate et al. (1980), and Hill and Haywood (1988) preferred a westward-dipping subduction zone even in the northern Appenines; in this scenario, the westward-verging nappes of Corsica can be viewed as backthrusts (i.e., arcward-verging thrusts) at the landward edge (i.e., western edge) of the accretionary prism above a westward-dipping subduction zone (Treves, 1984). An appealing aspect of the westward-dipping subduction zone is that it eliminates the need for a polarity reversal (Boccaletti et al., 1971) between Cretaceous (controversially dipping) and Eocene-Oligocene (unambiguously westward-dipping) subduction.

The direction of dip of the Cretaceous to Oligocene subduction zone or zones is important to this study because of its influence on the inherited fabric of the continental crust that was subsequently stretched to form the Tyrrhenian Basin. Accretion above a subduction zone that dips eastward or toward Apulia would produce primarily westward-verging (eastward-dipping) thrust faults; whereas, the accretionary complex above a westward-dipping subduction zone would be dominated by westwarddipping thrust faults. It has been proposed that rifting of the Tyrrhenian Sea proceeded by asymmetrical extension above a shallow detachment fault that dipped east (Kastens, Mascle, et al., 1988) or west (LaVecchia, 1988). An eastward-dipping detachment fault could reactivate thrust faults formed at an accretionary complex above a subduction zone that dips toward Apulia. A westward-dipping detachment fault could reactivate thrust faults formed in an accretionary complex above a westwarddipping subduction zone.

Under the northern Tyrrhenian Sea, at the latitude of southern Corsica, westward-dipping seismic reflectors can be detected within the "acoustic basement" (Zitellini et al., 1986, Figs. 3 and 5). Zitellini et al. (1986, p.28) describe these features as "Apennine verging tectonic units," thus implying that at least in this northernmost part of the Tyrrhenian, "basement" makes up eastward-verging, westward-dipping imbricate thrust packets. The age of these basement reflectors is unknown. Northeastward-verging thrusts, of inferred Miocene age, have also been documented beneath the continental shelf and slope near Naples (Bartole et al., 1984).

[3] However, arenites within the Messinian sediments of Site 652 contain mudstone clasts with planktonic foraminifers of Paleogene age, which Borsetti et al. (this volume) interpret as derived from a deep-water carbonate turbidite facies. If this interpretation is correct, the Paleogene morphology of the future lower Sardinia margin must have included at least local pockets of deep water.

[4] Dewey et al. (in press) believe that this oceanic crust might could be as old as Jurassic time, whereas Dercourt et al. (1986, Pl. 4) showed a spreading center of Aptian (mid-Cretaceous) age at this location.

[5] We use "Northern Balearic Basin" in the sense of Dewey et al. (in press, their Fig. 4) to mean approximately the area bounded by Corsica, Sardinia, and the Mediterranean coastline of mainland France. The basin between Corsica and mainland France probably opened at a different time and/or a different rate than the area between Sardinia and France (Alvarez et al., 1974; Burrus, 1984; Dewey et al., in press).

[6] Burrus (1984) placed the transition from stretching of continental crust to formation of basaltic crust by seafloor spreading in Aquitanian time (23.7-21.8 Ma on the time scale of Berggren et al., 1985). This date is based primarily on the identification in the Gulf of Lyons (Burrus, 1984, his Figs. 9 and 11) of magnetic anomaly 6B (normally reversed) and the reversely magnetized anomaly that immediately proceeded $6 \mathrm{~B}$. Two additional lines of evidence are based on stratigraphic relationships: First, a north-northwest/south-southeast trending rift on Sardina, thought to be a failed or aborted rift of the Northern Balearic system, became inactive in the middle to upper Aquitanian (Cherchi and Montadert, 1982). Second, major marine transgressions occurred in southwestern Sardinia and southern France, as might be expected when seafloor spreading and thermal subsidence began in the adjacent basin (Alvarez, 1974; Hill and Hayward, 1988).

Rehault et al. (1984) proposed a younger (Burdigalian) age for the rift to drift transition, based on three lines of reasoning. First, they believed that the onset of the paleomagnetically constrained counterclockwise rotation of Sardinia (Montigny et al., 1981) at 21 Ma coincided with the rift to drift transition. Second, they noted that the western Mediterranean margins experienced transgressions in both the Aquitanian and the lower Burdigalian, but that the Burdigalian transgression was more important (no reference given). Third, they reported that DSDP Site 372 bottomed in lower and middle Burdigalian sediments and that drilling was halted just before penetrating the post-rift unconformity; thus, rifting must have begun in the lower Burdigalian.

[7] Burrus's (1984) interpretation of magnetic anomalies in the Gulf of Lyons implied that the end of large-scale accretion of oceanic crust northwest of Corsica/Sardinia occurred within magnetic anomaly 6, i.e., 19.35 to $20.45 \mathrm{Ma}$, early to middle Burdigalian. (But see Rehault et al., 1984a, for the alternative suggestion that the central, normally magnetized anomaly is anomaly 5D). Potassium/argon (K/Ar) dating and paleomagnetic declination measurements of volcanic rocks from Sardinia show that Sardinia rotated $30^{\circ}$ counterclockwise sometime between 18 and $21 \mathrm{Ma}$, probably between 19 and $20 \mathrm{Ma}$ (Montigny et al., 1981, Fig. 4). If, as seems likely, the rotation of Sardinia was caused by the same process that caused the opening of the northern Balearic Sea, then cessation of Balearic Sea seafloor spreading could not have occurred before $19 \mathrm{Ma}$. Minor extrusive vulcanism along the former spreading center probably continued somewhat later. A sample of tristanite dredged from near the axis of the inferred Ligurian Sea spreading ridge has been $\mathrm{K} / \mathrm{Ar}$ dated at $18 \pm 0.5 \mathrm{Ma}$ (Rehault et al., 1984).

[8] Based on seismic stratigraphy, Moussat (1983) and Rehault et al. (1987) called for significant extension and subsidence in the early and 
middle Miocene; Rehault et al. (1987) envisioned extension as far back as the late Oligocene, coeval with rifting in the north Balearic basin. Their evidence is the "large thickness of the pre-Messinian sediments" (Unit "B3," Rehault et al., 1987, p. 134; cf. Moussat, 1983, p. 81). However, the greatest mapped thickness of Unit B3 (Fig. IV-19, Moussat, 1983) is only $0.9 \mathrm{~s}$ or approximately $1 \mathrm{~km}$. A sedimentation rate of less than $20 \mathrm{~cm} / \mathrm{k}$.y. would deposit such a sediment column over the 6 Ma duration of the Tortonian. This sedimentation rate is not unusually high for a continental margin setting, and thus sediment thickness alone is not a persuasive argument in favor of pre-Tortonian rifting and subsidence. Malinverno (1980) estimated an age of 10 to $14 \mathrm{Ma}$ for the Tyrrhenian by using McKenzie's (1978) model of thermal subsidence to fit constraints of bathymetry and heat flow. However, Wang et al. (1989) have reached an equally satisfactory fit to the heat flow and bathymetric data using a model in which rifting begins at $9 \mathrm{Ma}$ and proceeds by simple, rather than pure, shear. Malinverno and Ryan (1986) considered that the Tyrrhenian opening must have begun immediately after the end of the Corsica/Sardinia block rotation (i.e., about $17 \mathrm{Ma}$ ) because they envisioned uninterrupted retreat of the subduction zone of the AfricanAdriatic lithosphere. However, several well-documented cases exist where backarc spreading proceeded behind a given trench for a time, stopped for a while, and then resumed at a more seaward location (e.g., Parece Vela Basin/Mariana Trough, Hussong and Uyeda, 1982; Scotia Sea, Barker and Hill, 1981).

Perhaps the most persuasive line of evidence for an earlier (pre-Tortonian) phase of Tyrrhenian rifting was called to our attention by N. Zitellini (pers. comm., 1988). He pointed out that the seismic refraction data of Duschenes et al. (1986) indicated oceanic-type crust beneath the southern half of Cornaglia Basin, in a region with well-documented, thick Messinian evaporites (Fabbri and Curzi, 1979; Curzi et al., 1980). If Duschenes et al. (1986) interpreted their seismic data correctly, basaltic crust formation must have occurred in this region before the Messinian. In that case, pre-Tortonian rifting of the southern Cornaglia Basin may be plausible.

[9] A note on the age of the synrift sediments of Site 654: The sand and fanglomerate at the base of Hole 654A have not been directly dated. The base of the nannofossil ooze (Unit IV) is late Tortonian in age. It falls within nannoplankton Zone NN11a (i.e., 9.6-6.5 Ma, according to Mueller, 1985) and magnetic polarity Chron $7 \mathrm{n} 2$ (Channell, Torii, and Hawthorne, this volume; i.e., 6.85-7.28 Ma, according to Berggren et al, 1985).

Borsetti et al. (this volume) consider the age of lithologic Unit V (the sand) and conclude that it is probably conformable with the overlying nannofossil ooze, and thus Tortonian in age. An alternative hypothesis might be that the glauconitic sands are early Miocene in age; however, the contact between lithologic Unit V and Unit IV is transitional, without apparent unconformity.

The seismic reflector marking this apparent contact between the prerift and synrift sediments lies $150 \mathrm{~m}$ below the base of Hole 654A. Given the high rate of sedimentation expected in a fanglomerate, we tentatively estimate that the base of the synrift section is probably not more than 4 Ma older than the sediments at the base of the drilled section; that is, the base of the synrift section is most likely Tortonian in age. [Four million years is the difference between the age of $11.3 \mathrm{Ma}$ for the Serravallian/Tortonian contact (Harland et al., 1982) and the age of $7.3 \mathrm{Ma}$ for the base of magnetic polarity Chron $7 \mathrm{n} 2$, within which the oldest datable sediments occur.]

In any case, we can state with confidence that the region of Site 654 subsided through sea level during the Tortonian and that the prerift/synrift transition in the region of Site 654 is no younger than Tortonian.

[10] Seismic stratigraphy (without well control) has been interpreted to indicate Tortonian normal faulting and subsidence in the northern Tyrrhenian Sea (Zitellini et al., 1986) and along the Tyrrhenian margin of Calabria and Sicily (Barone et al., 1982). The primary lines of reasoning include (1) wedge-shaped geometry of the units between the acoustic basement and the inferred Messinian unit, and (2) normal faults that displace the acoustic basement and the pre-Messinian units, but not the Messinian units (A. Barone and N. Zitellini, pers. comm., 1988). An older limit for this pre-Messinian tectonism cannot be determined directly from available data. On the margins of Calabria and Sicily, a Tortonian age of subsidence is inferred because Tortonian marine sediments have been observed to transgress on crystalline and metamorphic basement in outcrops in Calabria and Sicily (Fabbri et al., 1980).
Extensional tectonism also began to encroach on the previously compressional territory of the Apennine chain. In western Tuscany and eastern Liguria, field mapping shows that grabens began to form in the late Tortonian (Lavecchia, 1988).

[11] The most commonly cited age for Vavilov Basin basement is 7.3 $\pm 1.3 \mathrm{Ma}$ at DSDP Site 373 (Barberi et al., 1978). In fact, the data set is too complex to summarize in a single date. The contact between biozone $\mathrm{MPl}-4 / \mathrm{NN1} 6$ and MPl-3/NN14, indicating an age of $3.6 \mathrm{Ma}$ (on the revised time scale of Rio et al., this volume) occurs $1.4 \mathrm{~m}$ above the contact between sediment and basalt breccia (Hsü et al., 1978). Ten K/Ar measurements performed by Barberi et al. (1978) and Kreuzer et al. (1978) on basalts from Core 7 (364-369 mbsf, approximately $100 \mathrm{~m}$ below the sediment/basalt contact), plus one measurement from Core 4 ( $287 \mathrm{mbsf}, 18 \mathrm{~m}$ below the sediment/basalt contact) cluster about a mean age of $4 \mathrm{Ma}$ (with a range of 3.0 to 5.6 and an average analytical uncertainty of $\pm 0.9 \mathrm{Ma}$ ). Two measurements on the same Core 7 by a different laboratory (Savelli and Liparinni, 1978) yielded K/Ar dates of 6.9 and $7.2 \mathrm{Ma}$ (with an analytical uncertainty of $\pm 0.8 \mathrm{Ma}$.). Deeper in the section (Core 12, $448 \mathrm{mbsf}, 180 \mathrm{~m}$ below the sediment/basalt contact), two measurements by Barberi et al. (1978) indicated ages of 6.8 and 7.5 Ma (with analytical uncertainties of \pm 1.2 to $1.3 \mathrm{Ma}$ ). In the same Core 12, Savelli and Liparinni (1978) found a K/Ar date of 4.4 $\mathrm{Ma}$, with no error bar indicated. In the face of this sparse and contradictory $\mathrm{K} / \mathrm{Ar}$ data, we place the most confidence in the date of approximately $4 \mathrm{Ma}$ at Core 7 , which was obtained by two different laboratories on a large number of samples. Moreover, this date is compatible with the biostratigraphic ages obtained within the basalt breccia and just above the sediment/basalt contact.

We are not certain how to interpret the 6.8 and $7.5 \mathrm{Ma}$ dates that Barberi et al. (1978) obtained from Core 12. Barberi et al. (1978, p. 511) envisioned a slow, but more or less steady, rate of basaltic crust formation from late Miocene to early Pliocene. Alternatively, there may have been more than one discrete episode of basaltic vulcanism at this site. Significant differences in basalt texture and chemistry among samples from Core 7 (a low-Ti, amygdaloidal basalt interbedded between basalt breccias) and Core 12 (a high-Ti flow basalt) (Detrich et al., 1978; Hsü et al., 1978) may support the latter interpretation. Coring at Site 373 was too spotty to test this hypothesis.

[12] The 6.5 to $4.8 \mathrm{Ma}$ age span for the Messinian is based on Leg 107 data, primarily the work of Channell et al. (this volume) on Sites 652 and 654 . In the paleomagnetic interpretation preferred by Channell et al., the Tortonian/Messinian boundary at Site 654 falls within the lower half of Chron 6 (6.70-6.37 Ma on the time scale of Berggren et al., 1985; equivalent to Subchron $3 \mathrm{~B} / 3 \mathrm{Br}$ of $\mathrm{Cox}, 1982,6.55-6.42 \mathrm{Ma}$ ). In an alternative interpretation, presented but not favored by Channell et al. (this volume), the Tortonian/Messinian boundary would fall within Subchron $3 \mathrm{~A} / 3 \mathrm{Ar}$ of $\mathrm{Cox}$ (1982). The discrepancy between the nannoplankton- and foraminifer-based determinations of the Messinian/Tortonian boundary at Site 654 (see note [13]) compounds the uncertainty about this date.

Channell et al.'s (this volume) paleomagnetic dating at Sites 652 and 654 places the Miocene/Pliocene boundary just below the top of the lowermost reversely magnetized interval of the Gilbert polarity chron (Chron $3 \mathrm{r}$ of Cox, 1982). This date of $4.8 \mathrm{Ma}$ is approximately $0.5 \mathrm{Ma}$ younger than most previously accepted interpretations (e.g., Cox, 1982; Berggren et al., 1985), although it is consistent with recent research on land sections in Calabria (Channell et al., this volume, and references therein) and in open-ocean DSDP sites (Keigwin, 1987). As Leg 107 results have not caused us to significantly shift the date of the Tortonian/ Messinian contact, the net result of this revised magnetostratigraphy is a Messinian stage that is about one and one-half times as old as previously envisioned, i.e., $\sim 1.5 \mathrm{Ma}$ rather than $\sim 1.0 \mathrm{Ma}$ ago.

[13] The Messinian/Tortonian boundary as defined by calcareous nannofossil markers and the boundary defined by planktonic foraminifer markers are not synchronous. The first occurrence of nannofossils Amaurolithus delicatus, A. primus, and $A$. tricorniculatus (equivalent to the contact between Zones NN11a and NN11b) is at 384.0 mbsf (Mueller et al., this volume). The base of the planktonic foraminifer Globorotalia conomioza biozone is at 369.6 mbsf (Glacon, Vergnaud Grazzini, Iaccarino, et al., this volume).

[14] We extrapolated the figure of several hundred thousand years from the slope of the paleomagnetic age vs. sub-bottom depth curve preferred by Channell et al. (this volume, their Fig. 12A). Channell et 
al.'s shallowest data point in lithologic Unit IV is at $358 \mathrm{mbsf}$; thus, this extrapolation covers 11 or $26 \mathrm{~m}$ (depending on whether one extrapolates from the Messinian/Tortonian boundary as determined from nannofossil markers or from foraminifer markers). The lithology of the interval covered by the extrapolation is uniform nannofossil ooze.

[15] Lowermost Messinian values of $\delta^{18} \mathrm{O}$ reach +0.83 to $1.09 \%$, in contrast to Tortonian values that average $-0.7 \%$ (Glacon, Vergnaud Grazzini, et al., this volume).

[16] Mean total organic carbon in Unit III equals $1.56 \%$, as contrasted with $0.07 \%$ in Pliocene and $0.32 \%$ in Tortonian sediments from the same hole (Emeis et al., this volume).

[17] $\delta^{18} \mathrm{O}_{\mathrm{PDB}}$ is greater than $+7 \%$ (Pierre and Rouchy, this volume). However, J. McKenzie (pers. comm., 1988) suggests an alternative explanation: dolomite precipitated within anoxic sediments, as for example, in the Messinian Tripoli Formation of Sicily or in Quaternary sediments of the Gulf of California, may be enriched in ${ }^{18} \mathrm{O}$ without requiring high evaporation rates (Kelts and McKenzie, 1984).

In lithology and stratigraphic position, Site 654 lithologic Unit III is reminiscent of "varvelike dolomite-bearing nannofossil marls" recovered beneath gypsiferous Messinian evaporites at DSDP Site 372 on the Menorca Rise (Core 9, Sections 1 and 2, Shipboard Scientific Party, 1978 , p. 68). The varvelike sediments are probably Messinian in age (Cita, Colalongo, et al., 1978). Both a hyposaline (Melieres, 1978) and a hypersaline (Cita et al., 1978) environment of deposition have been proposed for these Site 372 sediments.

[18] The strontium isotopic composition of rivers entering the Mediterranean is lighter than Mediterranean or open-ocean waters. Thus, it is somewhat paradoxical that in the gypsiferous Messinian sequence of Site 654, the gypsum-poor intervals exhibit the lightest $\mathrm{Sr}$ ratios, whereas the gypsum-rich intervals have heavier $\mathrm{Sr}$ isotopes (although still lighter than seawater). This should not be the case if gypsum-poor intervals represent times of flooding with [heavy-Sr] marine water, and gypsum-rich intervals represent times when closing of the "floodgate" to the Atlantic cut off ingress of [heavy-Sr] marine waters. Mueller et al. (this volume) note, but do not completely resolve, this paradox. We suggest that the paradox could be resolved if climatic variability within the Mediterranean Basin, rather than variability of Atlantic-derived influx were the major cause of gypsum-rich/gypsum-poor cycles. One could envision a more or less steady trickle of Atlantic-derived [heavy-Sr] marine water and a highly variable influx of [light-Sr] rainfall and runoff. During drier intervals, gypsum-rich sediments would be deposited with $\mathrm{Sr}$ ratios that are intermediate between those of rivers and seawater. During rainier intervals, gypsum-poor sediments would be deposited with light strontium isotopic ratios, reflecting major riverine influx.

[19] All but two of the paleomagnetic samples in the gypsiferous Messinian were reversely magnetized. Channell et al. (this volume) believe that most of these samples belong to the lowermost reversed interval of the Gilbert Chron, i.e., Subchron 3r of Cox (1982). At Site 652, where the Miocene/Pliocene boundary and the lower Pliocene section are most complete, the top of Subchron $3 \mathrm{r}$ is slightly $(\sim 5 \mathrm{~m}$, according to Channell et al., this volume, Fig. 7; or $\sim 50,000 \mathrm{yr}$, according to sedimentation rate derived from Channell et al., this volume, their Fig. 9) above the top of the Messinian. The duration of Subchron $3 \mathrm{r}$ is about 600,000 yr (between 4.79 and $5.41 \mathrm{Ma}$, according to Cox, 1982; or between 4.77 and $5.35 \mathrm{Ma}$, according to Berggren et al., 1985). Thus, the duration of the Messinian part of Subchron 3r would be about 600,000 $-50,000$ yr or about $550,000 \mathrm{yr}$.

Channell et al. tentatively suggest that the lowermost $\sim 20 \mathrm{~m}$ of gypsiferous Messinian (lithologic Unit II) of Site 654 belongs to magnetic polarity Chron 5 (5.35-5.89 Ma on the time scale of Berggren et al., 1985; equivalent to Chron 3A of Cox, 1982, 5.41-5.70 Ma). This interpretation requires an unconformity near the base of the gypsiferous Messinian (approximately 305 mbsf, Channell et al., this volume, their Fig. 10). Independent evidence for such an unconformity includes (1) the occurrence of a breccia at about this same level (Core 107-654A-35, $\sim 302$ mbsf, Shipboard Scientific Party, 1987e), (2) a slight angular unconformity on the seismic reflection profile crossing Site 654 (Fig. 6; $\sim 330$ ms below seafloor at the drill site), (3) the observation that $\mathrm{Sr}$ isotope ratios within lithologic Unit II below the alleged unconformity are more similar to those in the underlying Unit IV than to those in the rest of Unit II (Mueller et al., this volume), and (4) the inference that the recovered section represents only the gypsiferous "upper evaporites" (e.g., Decima and Wezel, 1973) and that the halite-bearing "lower evaporites" are missing.
If Channell's proposed identification of the base of Subchron $3 \mathrm{r}$ is correct, the duration of evaporitic sedimentation at Site 654 must be longer than the duration of the Messinian portion of Subchron 3r, i.e., longer than 550,000 yr. If Channell's unconformity is correctly identified, the maximum possible span of evaporitic conditions would be on the order of $1,000,000 \mathrm{yr}$ (from just below the top of reversed polarity Subchron $3 \mathrm{r}$ to somewhere within reversed polarity Subchron $3 \mathrm{Ar}$ in the terminology of Cox, 1982); much of this million or so years would have been an interval of nondeposition.

An alternative interpretation of the paleomagnetic data, suggested but not favored by Channell et al. (this volume), would consider that Subchron 3r (of Cox, 1982) encompasses all of the gypsiferous Messinian (lithologic Unit II), all of the silica-bearing Messinian (lithologic Unit III), and part of the open-marine Messinian (lithologic Unit IV down to about $358 \mathrm{mbsf}$ ). In that case, the duration of the evaporative Messinian episode would be much less than the duration of Subchron 3 r, i.e., much shorter than 550,000 yr.

[20] The dolomite is interpreted as Messinian, based on analogy with uppermost Messinian lithologies observed elsewhere (e.g., DSDP Site 374). The conglomerate cannot be directly dated, but the transitional nature (Shipboard Scientific Party, $1987 \mathrm{~g}$, p. 959) of its contact with the overlying dolomite suggests that the conglomerate is conformable with the dolomite, and thus probably Messinian in age.

[21] Although we follow the preferred interpretation of the shipboard paleomagneticists in this chapter, we note that other interpretations are plausible. Cita et al. (this volume) propose an alternative event stratigraphy, whereby the drilled pre-Pliocene section at Site 652 coincides approximately with the entire Messinian stage, including the preevaporative Messinian. Broglia et al. (this volume) point out that the pebble layer (lithologic Unit IVC) could represent a hiatus encompassing magnetostratigraphic Chron 5; in that case, the base of the hole could be correlated to the top of the Tortonian. Borsetti et al. (this volume) suggest that the sediments above the pebble layer could be correlative with the terminal Messinian "lago-mare" event. On the basis of variations in clay mineral abundances, Chamley et al. (this volume) correlate the upper $220 \mathrm{~m}$ of the Site 652 barren sequence with the entire Messinian plus the uppermost Tortonian section at Site 654. Finally, Robertson (this volume) correlates the Site 652 pebble layer with the intraMessinian unconformity observed in Sicily (Decima and Wezel, 1973).

[22] The presence of reworked Cretaceous and Paleogene nannofossils (Mueller, this volume) rules out the alternative hypothesis that autochthonous marine fossils had been deposited but then were diagenetically removed by reaction with interstitial water of unusual chemistry. Since Hole $652 \mathrm{~A}$ was terminated before reaching the base of the inferred Messinian section, marine-derived evaporites could still underlie the cored section.

[23] Mean total organic carbon in pre-Pliocene samples is $0.42 \%$ vs. $0.24 \%$ for Pliocene sediments from the same site (Emeis et al., this volume).

[24] Average $\delta^{18} \mathrm{O}$ PDB is $-4.4 \%$, as contrasted with +0.86 to $+1.17 \%$ in the lower Pliocene of the same site and an average of $-2.5 \%$ in the Messinian of Site 654 (Pierre and Rouchy, this volume).

[25] Because of the poor age constraints for the Site 652 pre-Pliocene sediments, Broglia et al. (this volume) declined to discuss the periodicity of their observed cycles. We can note, however, that their Figure 8 shows 53 coarse/fine cycles in $130 \mathrm{~m}$ of lithologic Unit IV, or roughly $2.5 \mathrm{~m} /$ cycle. If the sedimentation rate was on the order of $1 \mathrm{~m} / 1000 \mathrm{yr}$ (i.e., 500,000 yr to deposit the entire drilled pre-Pliocene section), then the coarse/fine cycles would have a period on the order of 2,500 yr. This rough calculation should not be taken too literally. However, one can hypothesize that the cycles are almost certainly too long to be annual and probably too short to be Milankovitch-type orbital variations (Hays, 1976), but may possibly be of the right duration to be solar variations (Suess, 1980).

[26] Pierre and Rouchy (this volume) consider that the stable isotopes of the Site 652 sulfate samples conclusively indicate a marine origin for the waters from which the sulfates were precipitated. Although the observed isotopic ratios $\left(\delta^{34} \mathrm{~S}:+19.8\right.$ to $+24.5 \%$; $\delta^{18} \mathrm{O}:+13.7$ to $+17.5 \%$ ) are certainly compatible with a marine origin, in our opinion they do not by themselves require a marine origin. A wide range of sulfur and oxygen isotope values, overlapping those measured in Site 652 sulfates, can be seen in lakes fed entirely by terrestrial waters (B. Lyons, pers. comm., 1989). 
[27] Borsetti et al. (this volume, their Fig. 3) document a gross upsection-fining trend from the indurated sandstone of prerift lithologic Unit $\mathrm{Vb}$, to the occasional sand layers in a dominantly pelitic sediment of Unit Va, to closely spaced alternations of mud and silt in Unit IV. Broglia et al. (this volume, Fig. 8) use a combination of downhole logs to document a more subtle upsection-fining trend within Unit IV.

[28] A downsection decrease of smectite and kaolinite paralleled by a downsection increase in chlorite, illite, and mixed layer clays (Chamley et al. this volume).

[29] Today's heat flow averages $134 \pm 31 \mathrm{~mW} / \mathrm{m}^{2}$ on the lower Sardinia margin (Rehault et al., this volume, Region C) and $84 \pm 29 \mathrm{~mW} /$ $\mathrm{m}^{2}$ on the upper margin (Rehault et al., this volume, Region A). Thermal gradients averaged $14^{\circ} / 100 \mathrm{~m}$ in Hole 652A (Shipboard Scientific Party, 1987c) and $4.2^{\circ} / 100 \mathrm{~m}$ in Hole 654A (Shipboard Scientific Party, 1987e). Emeis et al. (this volume) imply that their observations required even higher temperatures at Site 652 in the past, whereas Chamley et al. (this volume) imply that their observations could be accounted for by the modern contrast in thermal gradient at Site 652 vs. Site 654 .

[30] Kastens, Mascle, et al. (1988) and Kastens (1988) stressed that rifting was apparently diachronous in the across-strike (east-west) direction, based on evidence that subsidence and tilting of fault-blocks began and ended earlier at Site 654 on the upper Sardinia margin than at Site 652 on the lower Sardinia margin. We now believe that rifting on the Sardinia margin was also diachronous in the along-strike (north-south) direction. Tricardi and Zitellini (1987, Fig. 2a) illustrated a convincing seismic reflection profile (BS17) from the upper Sardinia margin, approximately $160 \mathrm{~km}$ south of Site 654 , in which the top of the synrift wedge is significantly shallower than the inferred Messinian unit. If this seismic interpretation is correct, the fault-bounded block crossed by BS17 would have continued tilting after the faults bounding Site 654's block had become immobile.

[31] On Sardinia, a cycle of alkaline vulcanism began at about $5 \mathrm{Ma}$ and persisted into the Pleistocene (Beccaluva et al., 1977). Tholeiitic and alkaline eruptions began at about 5.4 Ma on Mt. Iblea, in southeastern Sicily, and continued through the Pliocene (Capaldi et al., 1985). Calc-alkaline eruptions began on the westernmost volcano of the Eolian arc, Aceste seamount, at about 5.2 Ma (Savelli, 1988).

[32] DSDP Site 376, lithologic Unit V: nannofossil dolomitic marlstone with interbedded graded sandstones and siltstones. DSDP Site 374, lithologic Unit IIIA: black dolomitic mudstone overlying evaporites and underlying lower Pliocene marls, lacks calcareous nannofossils and microfossils, but assigned to "lago-mare" facies by Cita et al. (1978), based on lithology and stratigraphic position. DSDP Hole 129A: dolomitic marl ooze.

[33] Robertson (this volume) has compared the pre-Pliocene dolomitic mud (lithologic Unit III) of Site 656 with lago-mare facies, based on its lithology and stratigraphic position. However, Cita et al. (this volume) believe that Site 656 Unit III should not be considered lago-mare facies because it lacks the distinctive brackish water fauna.

[34] The shipboard scientific party identified brightly colored sediments associated with the Miocene/Pliocene boundary in the following intervals: (1) Site 652 , lithologic Unit III, 188.2 to $188.6 \mathrm{mbsf}$; (2) Site 653, lithologic Unit IC, 209.1 to $216.6 \mathrm{mbsf}$; and (3) Site 654, base of lithologic Unit I, 237.2-242.0 mbsf. The reader should be cautioned that Robertson's (this volume) conclusions concerning basal Pliocene "metalliferous" sediments are based mainly on samples from outside these intervals.

[35] "Lago-mare" fauna were found in Cores 28 and 29 (Cita et al., this volume) whereas brightly colored, $\mathrm{Mn}$ - and Fe-enriched sediments were found in Core 26, Sections 4, 5, and CC. Two samples from Core 26 , Section 5, had an order of magnitude more $\mathrm{MnO}$ and three times as much $\mathrm{Fe}_{2} \mathrm{O}_{3}$ as did a sample from the lago-mare-bearing Core 28 (Robertson, this volume, his Table 4).

[36] Dates in the McKenzie and Sprovieri scenario were established by a linear interpolation between the Miocene/Pliocene boundary (considered as $4.9 \mathrm{Ma}$ ) and the top of the Thvera normal magnetic event (considered as $4.57 \mathrm{Ma}$ ), both in Hole 652A. Hole 652A is considered to have the most complete lower Pliocene section, because it has the largest number of warm/cold cycles (as indicated by oxygen isotope ratios and relative species abundances of planktonic foraminifers) downsection from the Sphaeroidinelopsis acme. Both Sites 653 and 654 are considered to be missing the base of the MPl1 foraminiferal biozone. If 4.8 Ma were used for the Miocene/Pliocene boundary, as proposed by Channell et al. (this volume), the timetable for McKenzie and Sprovieri's scenario would be slightly accelerated.
[37] The evidence for early Pliocene estuarine circulation is reviewed by Thunell et al., (1987). His first line of evidence is based on stable isotopes of carbon. The carbon isotope ratio (at present) of total $\mathrm{CO}_{2}$ in North Atlantic Deep Water (NADW) is about $1 \% 0$ lighter than that of surface water (Kroopnick, 1985), reflecting the longer subsurface residence time of the deeper water. Thus, a subsurface inflow of water derived from the NADW should lead to Mediterranean bottom water that is isotopically lighter than Mediterranean surface water. In contrast, the modern Mediterranean Sea has almost no surface-to-bottom ${ }^{13} \mathrm{C}$ gradient, because bottom waters are derived directly and quickly from surface waters by downwelling within the Mediterranean. Thunell et al., (1987) showed that $\delta^{13} \mathrm{C}$ values in early Pliocene Mediterranean benthic foraminifers from DSDP Site 132 are significantly lighter than those in planktonic foraminifers of the same age, as would be expected from an inflow of light-C subsurface Atlantic water. McKenzie and Sprovieri (this volume) have confirmed the existence of a sea surface-to-seafloor ${ }^{13} \mathrm{C}$ gradient on the order of 1 to $5 \%$ in sediments of early Pliocene (MPI1 and MPI2) age at Sites 652, 653, and 654.

The second line of evidence supporting an estuarine circulation pattern is that whereas the modern benthic fauna of the Mediterranean were warm-water ("thermospheric") species, the early Pliocene benthic fauna were cold-water ("psychrospheric") species normally found at depths of 500 to $1500 \mathrm{~m}$ in the North Atlantic. Benson $(1972,1973)$ first used this argument (with respect to ostracods) to suggest that the Gibraltar sill must have been lower in the early Pliocene. Van Harten (1984) extended the conceptual model to include a deeper Gibraltar sill plus an inward flow of water near the seafloor. Hasegawa et al. (this volume) present a similar scenario, featuring both a lower Gibraltar sill and a "deep-in, shallow-out" circulation pattern, to explain the occurrence in Leg 107 Pliocene sediments of benthic foraminiferal species that are typically associated with the NADW mass.

In passing we note that the observation of "psychrospheric fauna" in lower Pliocene Mediterranean and circum-Mediterranean sediments cannot be used to rule out the scenario proposed by McKenzie and Sprovieri (this volume) in which collapse of the Gibraltar sill is delayed until about $200,000 \mathrm{yr}$ after the Miocene/Pliocene boundary. The examples of Pliocene psychrospheric ostracods of which we are aware (Benson, 1973; van Harten, 1984; Colalongo et al., this volume) are all in MPI2 or younger sediments; likewise, the benthic faunal assemblages that Hasegawa et al. (this volume) associate with the NADW (their Assemblages B, C, and D) are first found in biozone MPI2.

[38] The reasoning behind this hypothesis is that the $2.5 \mathrm{Ma}$ event in the Tyrrhenian is marked by a increase of $0.9 \%$ in oxygen isotopes, whereas in the Atlantic the same event is marked by a shift of only $0.5 \%$. The extra $0.4 \%$ in the Mediterranean is attributed to increased evaporation (or decreased rainfall and runoff) in the Mediterranean watershed (Vergnaud-Grazzini et al., this volume). Studies on pollen (Suc, 1984) support the contention that the circum-Mediterranean climate became more arid between 3.2 and $2.3 \mathrm{Ma}$.

Leg 107 data may provide additional support for the idea of drastically reduced fluvial influx at $\sim 2.5 \mathrm{Ma}$. McKenzie et al. (this volume) report a sharp increase in the ${ }^{87} \mathrm{Sr} /{ }^{86} \mathrm{Sr}$ ratios at this same time. The rivers feeding the Mediterranean today all have light $\mathrm{Sr}$ isotope values (Mueller et al., this volume, and references therein); thus, a decrease in runoff should result in an increase in ${ }^{87} \mathrm{Sr} /{ }^{86} \mathrm{Sr}$ ratios.

Loubere (1987) suggested an earlier date $(\sim 2.9 \mathrm{Ma})$ for the establishment of the Mediterranean outflow, based on his examination of cores from immediately outside the Straits of Gibraltar.

[39] An argument against a Pleistocene date for the switch from estuarine to anti-estuarine circulation can be constructed, based on the distribution of sapropels in Leg 107 cores. Anomalously low ${ }^{18} \mathrm{O} /{ }^{16} \mathrm{O}$ ratios in planktonic foraminifers from sapropels and sapropelitic layers suggest that the sapropel-forming events were temporally associated with an increase in freshwater influx (Thunell et al., this volume, and references therein). During a period of estuarine circulation, an abnormally high influx of freshwater from either rainfall or runoff should increase the flow of low-salinity near-surface water out of the Mediterranean, thus enhancing and invigorating the prevailing circulation pattern. On the contrary, during a period of anti-estuarine circulation, a pulse of freshwater added to the Mediterranean should counter the prevailing pattern of eastward flow of near-surface water from the Atlantic. This same influx of freshwater should negate the prevailing tendency of evaporation to exceed precipitation and runoff, and thus diminish the vigor of downwelling in the eastern Mediterranean. In short, increased influx of freshwater to an estuarine Mediterranean might lead 
to more vigorous circulation, whereas increased influx of freshwater to an anti-estuarine Mediterranean would lead to more sluggish circulation.

If followed to its logical conclusion, this line of reasoning would suggest that an anti-estuarine circulation pattern is a prerequisite for the formation of sapropels by the "freshwater lens" mechanism. If this reasoning is correct, then the conversion from estuarine to anti-estuarine circulation must predate the occurrence of abundant sapropels. With the exception of two sapropelitic layers in the lower Pliocene of Site 654, all 48 sapropels and sapropelitic layers recovered in Leg 107 cores occur between $2.2 \mathrm{Ma}$ and the present. Five sapropels and sapropelitic layers occur between 2.2 Ma and the Pliocene/Pleistocene boundary (Emeis et al., unpubl. data, 1988). Thus, we infer that the switch from estuarine to anti-estuarine circulation did not occur in the Pleistocene, but did occur prior to $2.2 \mathrm{Ma}$.

[40] Hasegawa et al. (this volume) identify an even shallower (upper epibathyal) assemblage in the lowermost Pliocene of Sites 652 and 654 . However, this assemblage is characterized by a species tolerant of lowoxygenated bottom waters, Uvigerina pygmea. McKenzie and Sprovieri (this volume) associate the appearance of this species with a catastrophic reorganization of watermasses, recorded in the stable isotope record and possibly caused by the collapse of the Gibraltar sill. If this postulated catastrophic physical oceanographic event is real, the presence or absence of Uvigerina pygmea in this time interval probably has little or no paleobathymetric significance.

[41] Throughout the Mediterranean, the Miocene/Pliocene contact is typically marked by a conspicuous seismic reflector (named the "Y" reflector by Selli and Fabbri, 1971; and the "M" reflector by Ryan et al., 1971; both names are still in use). The M or Y reflector can represent an acoustic impedance contrast at the top of nonmarine Messinian lithologies, or an erosional surface in subaerially exposed regions (e.g., Malinverno et al., 1981). Seismic reflection data from the circum-Tyrrhenian frequently show an angular unconformity (the " $\mathrm{X}$ " reflector) in the inferred post-Messinian sediments (Selli and Fabbri, 1971; Barone et al., 1982; Bartole et al., 1984; Curzi et al., 1980; Zitellini et al., 1986; Trincardi and Zitellini, 1987; and many others). Selli and Fabbri (1971) sampled the units above and below the $\mathrm{X}$ reflector, where it outcrops in two submarine canyons. At these canyons, Selli and Fabbri (1971) found that the $\mathrm{X}$ unconformity is of middle Pliocene age, and they suggested that it correlates with a mid-Pliocene transgression recorded in Pliocene sections outcropping in the Appenines and on Sicily. Zitellini et al. (1986) and Trincardi and Zitellini (1987) suggested that the X reflector may be considered as a "breakup unconformity," i.e., a record of the cessation of motion on basement-involved normal faults, and the beginning of basinward flexure of the margin under the influence of thermal subsidence. The common occurrence of the $\mathrm{X}$ reflector in the northern Tyrrhenian and on the continental margins of Sicily and peninsular Italy (as well as Sardinia) is taken as evidence that the Pliocene subsidence documented on the Leg 107 drilling transect was part of a basinwide phenomenon.

The observation that the $\mathrm{X}$ reflector is of Pliocene age, and the inference that it is a "breakup unconformity," are consistent with our determination of the synrift/postrift contact within the Pliocene section of Site 652 . At Site 654 , however, we believe that the synrift/postrift contact is more likely to be within the uppermost Messinian or at the Messinian/Pliocene boundary. Unfortunately, the physiography of the Tyrrhenian's rifted margins, with their numerous, small, fault-bounded basins, has made it impossible to determine whether the $\mathrm{X}$ reflector is precisely correlative around the entire circum-Tyrrhenian; a slightly time-transgressive character of the $\mathrm{X}$ reflector cannot be ruled out with available data (N. Zitellini, pers. comm., 1988).

[42] Radiometric dates of Site 373 basalts cluster in the early Pliocene. See note [11]. Feraud (this volume) reports a $4.3 \mathrm{Ma}{ }^{39} \mathrm{Ar} /{ }^{40} \mathrm{Ar}$ age for basalts at Site 655 . There are problems with alteration of the samples, but Feraud seems cautiously confident of this result. This age is consistent with the observation that the entire basalt pile at Site 655 is reversely magnetized (Vigliotti et al.,this volume); $4.3 \mathrm{Ma}$ falls within the uppermost reversed interval of the Gilbert epoch. An early Pliocene age for the basalt emplacement is also consistent with the observation of biozones MP13 and NN15 at the base of the sediment column of Site 655 .

The age of the basalts at Site 651 is problematic. Feraud (this volume) reports an age of $3.0 \mathrm{Ma}$ for ${ }^{39} \mathrm{Ar} /{ }^{40} \mathrm{Ar}$ in the lower basalt (basement Unit 3) and an age of $2.6 \mathrm{Ma}$ for the upper basalt (basement Unit
1); however, he warns readers to view both dates with skepticism because the age spectra have been disturbed. These radiometric ages are incompatible with the observation that the upper and lower basalts at Site 651 are reversely magnetized (Vigliotti et al., this volume); the interval from 3.0 to $2.6 \mathrm{Ma}$ falls within the Gauss normal polarity epoch. The reverse magnetic polarity could potentially record the bottom part of the Matuyama polarity epoch $(1.88-2.47 \mathrm{Ma})$ or the top part of the Gilbert epoch (3.4-3.88 Ma; ages from Berggren, 1985). Vigliotti et al. (this volume) favor the Matuyama interpretation.

Rare specimens of Globoratalia crassiformis (Shipboard Scientific Party, 1987b, p. 310; Sartori, this volume) were found in a dolomite layer within basement Unit 2 of Site 651 . This species of planktonic foraminifers appears (somewhat diachronously) at about $3.2 \mathrm{Ma}$, becomes rare between 2.2 and $1.6 \mathrm{Ma}$, but then persists well into the Pleistocene (Glacon et al., this volume, their Figs. 2, 3, and 4). The G. crassiformis observation are thus compatible with either the Matuyama magnetostratigraphic interpretation or with the 3.0 to $2.6 \mathrm{Ma}$ radiometric date.

In the sediment column proper, the oldest datable sediments are located $40 \mathrm{~m}$ above basement. The sediment/basalt contact is at $388 \mathrm{mbsf}$. The top of the Reunion magnetic event (2.01 Ma; Cox, 1982) is tentatively identified at 347 mbsf, which is consistent with the determination of biozone MPl6 (2.09-1.65 Ma; Rio et al., this volume) in chalk at 348 mbsf. If the age vs. depth curve for the lower datable part of the sediment column (Shipboard Scientific Party, 1987b, their Fig. 15; or Channell, Torii, and Hawthorne, this volume, Fig. 5) is extrapolated back to the base of the sediment column, the age of the sediment basalt contact should be 3.5 to $3.7 \mathrm{Ma}$. This date occurs in the reversed interval at the top of the Gilbert magnetic epoch, and thus is consistent with the observation of reversed magnetic polarity in the basalt. Of course, this extrapolation is based on the unsupported assumption that the sedimentation rate in the red-brown basal sediments of Site 651 is the same as that in the overlying sediments. However, if one insists that the sediment/basalt contact occurs within the Matuyama reversed polarity epoch (i.e., is younger than $2.47 \mathrm{Ma}$ ), then one is forced to postulate a drastic change in sedimentation rate from less than $3 \mathrm{~cm} / \mathrm{k} . \mathrm{y}$. in the lowest datable sediments to more than $9 \mathrm{~cm} / \mathrm{k}$.y. in the undated lowest $40 \mathrm{~m}$ of the sediment column.

It is our opinion that the Site 651 basalts were probably erupted during the top of the Gilbert epoch, i.e., 3.4 to $3.88 \mathrm{Ma}$. However, additional efforts to date fossils in sediments within basement Units 2 and 3 , to date each of the basement units radiometrically and to examine the paleomagnetic signature of basement Unit 2, are clearly needed to weight these contradictory lines of evidence properly.

[43] On Magnaghi volcano, Pliocene age is based on radiometric dates of 3.0 and $2.7 \mathrm{Ma}$ of dredged basalts (Selli et al., 1977). With respect to Vavilov volcano, Barberi et al. (1978, p. 511) noted that the volcano is reversely magnetized (see also Pl. 1, Finetti and Del Ben, 1986) and suggested that it must have erupted in the Matuyama reversed magnetic chron (2.5-0.7 Ma). Robin et al. (1987) reported a biostratigraphically constrained late Pliocene age for sediments interbedded with basalt flows near the base of Vavilov volcano.

[44] This inference is based on the observation that the upper basalts of Site 651 are strongly enriched in rubidium, potassium, and lanthanum relative to normal mid-ocean ridge basalt (N-MORB); however, niobium is not enriched. Since niobium acts similarly to rubidium, potassium, and lanthanum in magmatic processes, the implication is that the mantle source for these basalts was enriched in rubidium, potassium, and lanthanum, but not niobium. Experimental data show that rubidium, potassium, and lanthanum are readily transported in aqueous fluids, whereas niobium is immobile. Consequently, Bertrand et al. (this volume) conclude that the mantle source for these basalts had been contaminated by volatiles escaping from the downgoing slab.

[45] In Kastens, Mascle, et al. (1988), we speculated that the bathymetric and structural sill that separates the Marsili and Vavilov basins could be a remnant volcanic arc that was active during the opening of Vavilov Basin. Without such a remnant arc, there is a gap in space and time between the Oligocene-Miocene-age calc-alkaline vulcanism on Sardinia and the Quaternary-age arc vulcanism of the Eolian Islands. Such a gap is somewhat surprising, given Karig's (1983) observation that backarc spreading is temporally associated with vigorous arc vulcanism in the western Pacific.

On further thought, in light of the near total lack of volcanic or volcaniclastic material recovered from Leg 107 Pliocene sediments, it seems 
likely that there really was an interval without voluminous arc vulcanism that corresponded to most or all of the Pliocene. Some local early Pliocene calc-alkaline vulcanism has been noted on the islands of Anchise and Aceste on the eastern continental slope of Sicily (Savelli, 1988, and references therein), but it is difficult to guess what its spatial relationship would have been with the paleo-Benioff zone.

Alternatively, a young volcanic arc may have been active but entirely submarine during the Pliocene. Thus, vulcanism was not explosive and tephras were not produced.

[46] As a possibly relevant fact, we note that the lower basalt unit of Site 651 (basement Unit 3) is thoroughly brecciated (Shipboard Scientific Party, 1987b, p. 305), whereas the upper basalt flows are more nearly intact. Perhaps the same action that emplaced the peridotite shattered a thin basaltic carapace. In that case, peridotite would have been emplaced post-basement-Unit-3 and pre-basement-Unit-1. Robertson (this volume) observes talc in dolomitic sediments within basement Unit 2 (Core 50). He suggests that the ultramafic body was exposed and weathered at the seafloor somewhere near Site 651 , and shed talc into the surrounding pelagic sediments. Exposure of the ultramafic body during accumulation of the basement Unit 2 sediments is compatible with the timing for emplacement of the peridotite envisioned above.

[47] One of the authors (Kastens, 1988) suggested that Site 651 peridotites originated beneath an island arc that was located east of the site and that slips along a major, eastward-dipping, low-angle detachment fault reduced the overburden above the upper mantle material and facilitated its protrusion up to a drillable level. This scenario still seems plausible. However, now that the Site 651 basalt has been shown to be calcalkaline (Beccaluva et al., this volume), we must also consider that the Site 651 peridotites might be refractory mantle material formed locally by partial melting beneath the backarc basin, rather than at a laterally displaced position beneath the island arc.

[48] Interestingly, one notes that even after the mid-Pleistocene increase, the glacial/interglacial $\delta^{18} \mathrm{O}$ contrast in Site 653 planktonic foraminifers is still less than $2 \%$. A similar glacial/interglacial contrast, $1.8 \%$, is found in the North Atlantic (Thunell et al., 1987, Table 2). This is surprising, in that Thunnell et al. (1987) showed a significantly higher glacial/interglacial contrast in the Mediterranean: $3.3 \%$ in the western Mediterranean and $4.4 \%$ in the eastern Mediterranean. These large numbers in the Mediterranean Sea come primarily from anomalously heavy isotopes during glacial stages, which Thunell et al. (1987) associated with increased salinity. The increased salinity, in turn, has been attributed primarily to decreased circulation through the Straits of Gibraltar (allowing more time for evaporation per unit volume of water) and secondarily to more arid climate. If the Tyrrhenian glacial/interglacial oxygen isotope contrast is less extreme than in the rest of the Mediterranean, does this mean that the circum-Tyrrhenian was less arid during glacial intervals than the rest of the circum-Mediterranean? Possibly supporting this idea, C. Müller (this volume) suggests that climate around the Tyrrhenian Sea may have been more humid than around the eastern Mediterranean, based on the presence of layers rich in Braarudoshaera bigelowi, a species indicative of less-saline surface waters. However, her observation pertains to the interval around the PliocenePleistocene boundary, rather than the upper Pleistocene. If the evaporation/runoff balance of the Tyrrhenian during glacial stages was in fact different from the rest of the Mediterranean, perhaps an explanation can be found in the fact that the Tyrrhenian drainage flows primarily from the north, whereas the eastern and western parts of the Mediterranean have long coastlines along arid Africa.

[49] Several attempts have been made to correlate the volume or frequency of turbidity currents with individual glacial/interglacial cycles, particularly in the upper Pleistocene section of Site 650 , where recovery approaches $100 \%$. The shipboard scientific party (1987a, p.143-144) attempted to correlate intervals of high carbonate concentration, low smectite concentration, and low magnetic susceptibility with interglacial stages. Their reasoning was that glacial stages should favor influx of volcaniclastic turbidites, thus diluting the influx of carbonates, increasing the influx of smectites, and increasing the influx of magnetites (and thus magnetic susceptibility). The details of this correlation cannot be supported by the oxygen isotope stratigraphy of Vergnaud Grazzini et al. (this volume).

Hieke et al. (this volume) attempt another correlation between fluctuations in sea level and turbidite deposition: they correlate the thickest recovered turbidite (92-132 mbsf at Site 650) with isotope stage 5, and attribute its deposition to sea-level transgression. This correlation is a bit surprising, since isotope stage 5 is a warm or interglacial stage, whereas turbidites are generally more common during lowstands of sea level (Shanmugan and Moiola, 1982). In our opinion it is unlikely that this megaturbidite was deposited during the major transgression between isotope stages 6 and 5 , because fauna of stage $5 \mathrm{e}$ have been recovered from beneath the turbidite (Hieke et al., this volume).

[50] Concerning the direction of extension of Marsili Basin: First, the Marsili volcano is markedly elongate north-northeast/south-southwest. Since volcanos tend to grow perpendicular to the direction of least horizontal compressive stress (Nakamura, 1977), this observation suggests extension along an east-southeast/west-northwest trend. Second, the magnetic anomalies exhibit a north-northeast/south-southwest trending positive anomaly centered over Marsili volcano, flanked on either side by negative anomalies (AGIP, 1981). This pattern is reminiscent of seafloor spreading anomalies about a north-northeast/south-southwest trending spreading center. Third, east-southeast/west-northwest trending bathymetric and structural trends in Marsili Basin and on Calabria (Moussat, 1983; Moussat et al., 1985; Dewey et al., in press) have been interpreted as strike-slip faults. We have said that the basin opens "toward the east-southeast," rather than symmetrically, because we believe that one of the driving forces for opening the basin was "rollback" (Malinverno and Ryan, 1986) or "passive subduction" (Ritsema, 1979) of the subduction zone.

[51] Concerning the rate of opening of Marsili Basin: The part of Marsili Basin having thin crust, high heat flow, deep water, and highamplitude magnetic anomalies is about 70 to $80 \mathrm{~km}$ across, measured west-northwest to east-southeast (Figs. 5, 7, and 8 in Rehault et al., 1987a). If extension similar to seafloor spreading began between 1.8 and 2.0 Ma ago, the rate of spreading integrated over the entire opening of Marsili Basin has been 3.5 to $4.5 \mathrm{~cm} / \mathrm{yr}$. The width of the central positive magnetic anomaly is approximately $22 \mathrm{~km}$. If this anomaly represents spreading during the 0.7 -Ma-long Brunhes epoch, the full spreading rate during this interval has been $3.1 \mathrm{~cm} / \mathrm{yr}$. These numbers are approximations, so the apparent decrease in spreading rate during the Brunhes should not be taken too seriously; however, one is tempted to associate the building of the volcanic edifice with a slowdown in extension, coupled with an unchanged rate of delivery of magma (Kastens, Mascle, et al., 1988).

[52] The basalt/sediment contact at Site 650 was encountered at $4118 \mathrm{~m}$ below sea level, beneath $602 \mathrm{~m}$ of sediment. Removing the weight of the sediment using an average sediment bulk density of 1.75 $\mathrm{g} / \mathrm{cm}^{3}$, derived from cores, gives a basement depth of approximately $3900 \mathrm{~m}$. Benthic foraminifers just above basement at Site 650 suggest a water depth of 1000 to $2000 \mathrm{~m}$ (Shipboard Scientific Party, 1987a, p. 149), although the assemblage is sparse. Similarly, the high degree of vesicularity of basalt at Site 650 suggests a shallow depth of eruption (Moore, 1965, 1970; Jones, 1969; Moore and Schilling, 1973), although this line of reasoning must be used with caution because of potentially high volatile content of the parent magma (Saunders and Tarney, 1979; Dick, 1980). Finally, seismic reflection profiles around the margin of Marsili Basin show extensive recent decrease in the level of the basin (the post-Messinian "foundering" of Selli and Fabbri, 1971). We estimated, conservatively, a depth of eruption of about $2500 \mathrm{~m}$ or shallower, and an age of eruption of $2 \mathrm{Ma}$ and thus derived a minimum rate of subsidence of 3900 to $2500 \mathrm{~m} / 2 \mathrm{~m} . \mathrm{y}$. or $700 \mathrm{~m} / \mathrm{m}$.y.

[53] The Pleistocene age for the Eolian Arc is based on K/Ar dating of dredged and subaerial samples (Beccaluva et al., 1985). Barone et al. (1982, their Fig. 4) suggested that this arc may have been partially built as long ago as middle Pliocene, based on seismic reflection profiles showing interfingering between the allegedly volcaniclastic aprons of several Eolian islands and basinal sediments immediately above the " $\mathrm{X}$ reflector." The X reflector has not been directly dated in this region, but is supposed to be mid-Pliocene in age. If the Eolian Arc is indeed Pliocene in age, the rapid increase in volcanogenic sediment observed in the late Pleistocene of Site 650 (between lithologic Units I and II, i.e., between nannoplankton Zones NN19 and NN20, about 500,000 yr ago) cannot be attributed to the birth of the Eolian Arc (Shipboard Scientific Party, 1987a, p. 169). However, the emergence of the Eolian Islands above sea level might potentially have caused the observed increase in volcaniclastic influx by exposing the seamount to subaerial erosion. If the Eolian Arc vulcanism began before the Pleistocene, the gap in duration between calc-alkaline vulcanism on Sardinia and calc-alkaline vulcanism on the Eolian Arc is slightly less long and thus slightly less puzzling.

[54] Savelli (1988) gave K/Ar dates of 0.37 and $<0.12$ Ma for samples from the Vavilov volcano. 